\title{
CNS cell-type localization and LPS response of TLR signaling
}

\section{pathways [version 1; peer review: 2 approved]}

\author{
Gizelle M. McCarthy (iD1,2, Courtney R. Bridges², Yuri A. Blednov², \\ R. Adron Harris (iD) 1-3 \\ ${ }^{1}$ Institute for Cellular and Molecular Biology, University of Texas at Austin, Austin, TX, 78712, USA \\ ${ }^{2}$ Waggoner Center for Alcohol and Addiction Research, University of Texas at Austin, Austin, TX, 78712, USA \\ ${ }^{3}$ Insitute for Neuroscience, University of Texas at Austin, Austin, TX, 78712, USA
}

\author{
V1 First published: $19 \mathrm{Jul} 2017,6: 1144$ \\ https://doi.org/10.12688/f1000research.12036.1 \\ Latest published: $19 \mathrm{Jul} 2017,6: 1144$ \\ https://doi.org/10.12688/f1000research.12036.1
}

\section{Abstract}

Background: Innate immune signaling in the brain has emerged as a contributor to many central nervous system (CNS) pathologies, including mood disorders, neurodegenerative disorders, neurodevelopmental disorders, and addiction. Toll-like receptors (TLRs), a key component of the innate immune response, are particularly implicated in neuroimmune dysfunction. However, most of our understanding about TLR signaling comes from the peripheral immune response, and it is becoming clear that the CNS immune response is unique. One controversial aspect of neuroimmune signaling is which CNS cell types are involved. While microglia are the CNS cell-type derived from a myeloid lineage, studies suggest that other glial cell types and even neurons express TLRs, although this idea is controversial. Furthermore, recent work suggests a discrepancy between RNA and protein expression within the CNS. Methods: To elucidate the CNS cell-type localization of TLRs and their downstream signaling molecules, we isolated microglia and astrocytes from the brain of adult mice treated with saline or the TLR4 ligand lipopolysaccharide (LPS). Glial mRNA and protein expression was compared to a cellular-admixture to determine cell-type enrichment. Results: Enrichment analysis revealed that most of the TLR pathway genes are localized in microglia and changed in microglia following immune challenge. However, expression of TIr3 was enriched in astrocytes, where it increased in response to LPS. Furthermore, attempts to determine protein cell-type localization revealed that many antibodies are non-specific and that antibody differences are contributing to conflicting localization results.

Conclusions: Together these results highlight the cell types that should be looked at when studying TLR signaling gene expression and suggest that non-antibody approaches need to be used to accurately evaluate protein expression.

\section{Open Peer Review Approval Status \\ 1 2 \\ version 1 \\ 19 Jul 2017

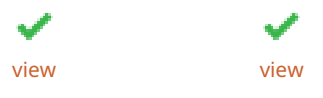 \\ 1. Eitan Okun (D), Bar-Ilan University, Ramat \\ Gan, Israel \\ 2. Miles Herkenham (D), National Institutes of \\ Health, Bethesda, USA}

Any reports and responses or comments on the article can be found at the end of the article. 


\section{Keywords}

Toll-like receptor, MyD88, TRIF, microglia, astrocyte, neuroimmune, lipopolysaccharide

Corresponding author: R. Adron Harris (harris@austin.utexas.edu)

Author roles: McCarthy GM: Conceptualization, Formal Analysis, Funding Acquisition, Investigation, Methodology, Validation, Visualization, Writing - Original Draft Preparation; Bridges CR: Investigation, Methodology, Validation, Visualization, Writing - Review \& Editing; Blednov YA: Conceptualization, Funding Acquisition, Investigation, Methodology, Project Administration, Resources, Supervision; Harris RA: Conceptualization, Funding Acquisition, Project Administration, Resources, Supervision, Writing - Review \& Editing

Competing interests: No competing interests were disclosed.

Grant information: Funding for this work was provided by the National Institute on Alcohol Abuse and Alcoholism (grants AA024654 and AA013520).

Copyright: ( 2017 McCarthy GM et al. This is an open access article distributed under the terms of the Creative Commons Attribution License, which permits unrestricted use, distribution, and reproduction in any medium, provided the original work is properly cited. Data associated with the article are available under the terms of the Creative Commons Zero "No rights reserved" data waiver (CC0 1.0 Public domain dedication).

How to cite this article: McCarthy GM, Bridges CR, Blednov YA and Harris RA. CNS cell-type localization and LPS response of TLR signaling pathways [version 1; peer review: 2 approved] F1000Research 2017, 6:1144 https://doi.org/10.12688/f1000research.12036.1

First published: 19 Jul 2017, 6:1144 https://doi.org/10.12688/f1000research.12036.1 


\section{Introduction}

Innate immune signaling has been well characterized in the body for decades, but the recent appreciation for its role in the brain has raised several questions. In particular, it has brought to light the similarities and differences between the immune response in the periphery and the central nervous system (CNS). At the center of this discussion are microglia, the resident immune cells of the brain. However, there is evidence that microglia have unique functions unrelated to immune signaling, and that other CNS cells can also participate in the immune response.

A key component of innate immunity is Toll-like receptors (TLRs), a family of pattern recognition receptors that detect and respond to pathogen and danger signals. TLRs respond to a variety of bacterial and viral pathogens, including the bacterial endotoxin lipopolysaccharide (LPS), which is a ligand for TLR $4^{1}$. In response to LPS, TLR4 with its co-receptor cluster of differentiation 14 (CD14) can signal through two distinct pathways, the myeloid differentiation primary response protein 88 (MyD88)-dependent pathway and the TIR-domain containing adaptor protein inducing IFN $\beta$ (TRIF)-dependent pathway ${ }^{2}$ (Figure 1). The MyD88dependent pathway signals through Interleukin 1 receptor associated kinases 1 and 4 (IRAK1 and IRAK4) and TNF receptor associated factor 6 (TRAF6), leading to activation of inhibitors of nuclear factor $\mathrm{\kappa B}$ Kinases (IKKs) $)^{1}$. Activation of IKKs causes activation of $\mathrm{NF}-\mathrm{KB}$ and the production of pro-inflammatory

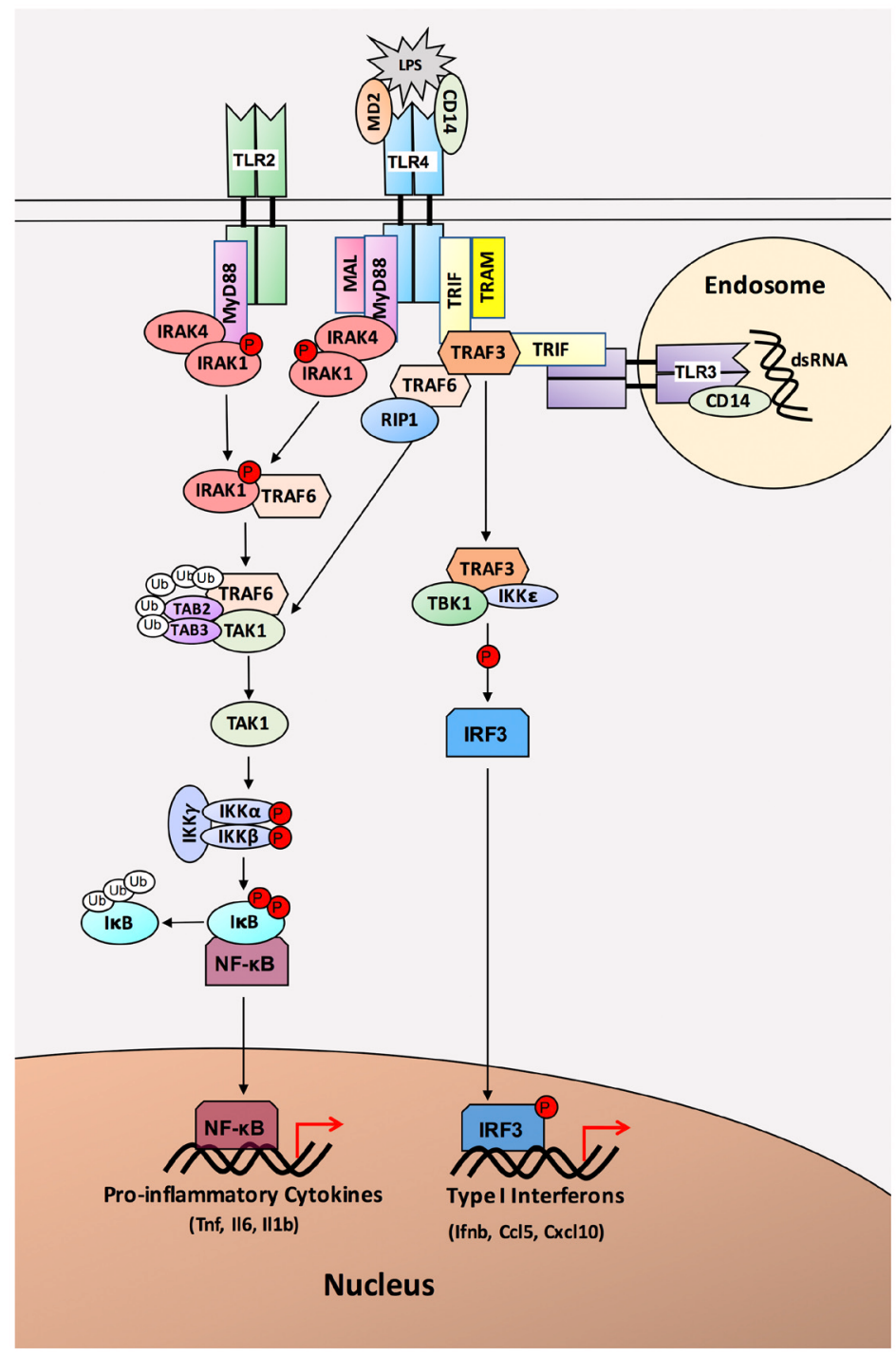

Figure 1. TLR-signaling pathways. Lipopolysaccharide (LPS) is recognized by TLR4 and its co-receptors MD2 and CD14. TLR4 signals through two different pathways, the MyD88-dependent pathway and the TRIF-dependent pathway. The MyD88-dependent pathway utilizes the adapter protein MyD88, which recruits IRAK4, IRAK1, and TRAF6. Phosphorylation of IRAK1 and ubiquitination of TRAF6 leads to activation of IKKs and NF- $\mathrm{KB}$. Activated NF-KB translocates to the nucleus where it promotes transcription of pro-inflammatory cytokines. TLR2 also signals through the MyD88-dependent pathway. The TRIF-dependent pathway, utilized by TLR3 and TLR4, signals through the adapter protein TRIF. TRIF recruits TRAF6 and TRAF3. Signaling through TRAF6 leads to NF- $\mathrm{KB}$ activation, while signaling through TRAF3 utilizes IKKE to activate IRF3. Activated IRF3 translocates to the nucleus, where it leads to transcription of Type I interferons and interferon inducible genes. 
cytokines (e.g. TNF, IL-1 $\beta$, IL-6). By contrast, the TRIF-dependent pathway utilizes the adaptor protein TRIF and signals through TRAF3, TBK1 and IKKE, leading to phosphorylation and activation of interferon regulatory factor 3 (IRF3) ${ }^{3}$. Activated IRF3 translocates to the nucleus where it leads to the transcription of type I interferons and interferon inducible genes (e.g. IFN- $\beta$, CCL5/ RANTES, CXCL10/IP-10).

TLR signaling has been implicated in several CNS conditions, including ischemia, neurodegeneration, depression, and addiction $^{4-9}$. However, the cell-type localization of TLR signaling within the CNS remains controversial and impairs our understanding and ability to develop treatments based on these signaling pathways. TLR signaling was originally characterized in peripheral immune cells; thus, it was believed that CNS expression of TLRs would be limited to microglia, the immune cells of the brain. Several studies support microglial expression of TLRs, and many reaffirm the idea that expression is completely or mostly microglial ${ }^{9-12}$. However, recent studies suggest that TLRs are also expressed and functionally important in other glial cells, such as astrocytes and oligodendrocytes ${ }^{10,11,13-18}$, or even non-glial CNS cells, like neurons ${ }^{19-24}$. These results are complicated by differences in methodologies across studies, including differences in: protein or mRNA; in vivo, primary cells or in established cell lines; species; and techniques. Interestingly, there seems to be disagreement between cell-type location of mRNA and protein expression for the same molecule, which raises many questions. For example, a brain RNA expression database shows Tlr4 as highly microglial ${ }^{25}$, while the human protein atlas (proteinatlas.org) shows it only detected in neurons ${ }^{26}$. Several other TLR signaling molecules (MyD88, IRAK1, TRIF, IRF3) also show highest mRNA expression in microglia, but highest protein expression in neurons.

Although many studies have reported the localization of TLRs in the CNS, few have evaluated the expression of the downstream signaling molecules and pathway outputs that are responsible for functional changes. It also remains unclear how immune activation might change cell-type expression of TLR signaling in vivo, as most studies have evaluated the response to TLR agonists using cultured

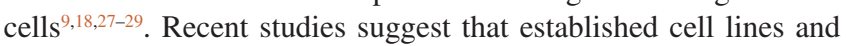
even primary cultured glial cells don't accurately reflect the expression profile in $v i v o^{30}$.

Although this discrepancy may seem esoteric, it is a major hindrance to the study of neuroimmune signaling. In our lab alone, we have had several problematic studies because it was unclear which cell type to use for a conditional knockout or viral vector, or a gene was knocked out in microglia but couldn't be verified on the protein level because of neuronal expression. These uncertainties not only result in wasted time and money, but also delay the discovery of important results. Given the key role of TLR signaling in CNS pathologies and the desire to manipulate and understand these pathways in the brain, it is imperative that cell-type localization of these molecules is determined and agreed upon.

Based on the disagreement in the field and preliminary results that suggested TLR-signaling mRNAs are localized in microglia while protein is localized in neurons, we sought to investigate
TLR signaling localization using glial cells isolated from adult mouse brain. The goals of this study were to identify the celltype enrichment of TLR pathway mRNAs and proteins with and without immune activation (LPS treatment), and to determine which cells exhibit expression changes following activation. There is literature supporting the idea that cell-type protein expression can change after LPS $^{31}$, so we hypothesized that key mRNAs will be abundant in microglia so to allow rapid translation into protein in response to immune activation. Our results revealed that mRNA was primarily microglial, although there were some differences in expression profiles, and that LPS increased mRNA expression in microglia. By contrast, our protein results were inconclusive, due to non-specific antibodies and conflicting results across antibodies for the same protein. Based on our results, we conclude that much of the disagreement in the field is due to antibody failures, and that better antibodies or alternative methods need to be developed to conclusively determine protein localization in CNS cells.

\section{Methods}

\section{Ethics statement}

All procedures were approved by the University of Texas at Austin Institutional Animal Care and Use Committee (animal protocol number AUP-2013-00061) and adhered to the National Instituted of Health Guidelines. The University of Texas at Austin animal facility is accredited by the Association for Assessment and Accreditation of Laboratory Animal Care. All efforts were made to ameliorate any suffering of the mice. Any mice that became too sick in response to the LPS injections were euthanized.

\section{Animals and LPS administration}

Studies were conducted in adult (6-8 weeks old) C57B1/6J male mice (Jackson Laboratories, Bar Harbor, ME, USA). Mice were individually housed and allowed to acclimate to upright bottles one week before the start of the experiment. The experimental rooms were maintained at an ambient temperature of $21 \pm 1^{\circ} \mathrm{C}, 40-60 \%$ humidity, and a regular light/dark schedule (7 AM-7 PM). Food and water were available ad libitum. The mice were randomly divided into three groups, each containing 7 LPS treated mice and 5 saline treated mice (additional mice were put in the LPS group in case of death before 24 hours) (Figure S1). The mice were weighed, had water intake measured for two days prior to injection and then were injected with either LPS $(2.0 \mathrm{mg} / \mathrm{kg})$ or saline. Mice were weighed and water intake was measured 24-hours post-injection and the mice were sacrificed with anesthesia. Weight and water consumption data is provided in Figure S2.

\section{Knockout animals}

Knockout (null mutant) mice for TLR2, TLR4, and MyD88 are described in 32. Briefly, the TLR2 knockout mouse was B6.129S1-Tlr2 ${ }^{\text {tmlDgen }} / \mathrm{J}$ (Jackson Laboratories), which has a neomycin cassette inserted in the gene, making it non-functional ${ }^{33}$. The TLR4 knockout mouse was B6.B10Scn-Tlr4 4 lps-del/JthJ (Jackson Laboratories), which has the locus containing the Tlr4 gene deleted ${ }^{34}$. The MyD88 knockout mouse was B6.129P2

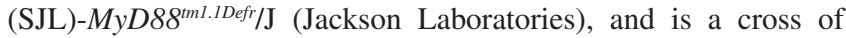
Myd88 $8^{\text {tmlDefr }}$ mice (loxP sites flanking exon 3 of Myd88) with $\mathrm{Tg}(\mathrm{Zp} 3-\mathrm{cre}) 93 \mathrm{Knw}$ mice ${ }^{35}$. RT-qPCR was used to determine the transcript expression in the knockout mice (Figure S3). The TLR2 
knockout mouse showed increased expression of $T l r 2$, which is consistent with a larger transcript being produced due to the neomycin cassette ${ }^{36}$. The TLR4 knockout mouse showed no transcript expression, consistent with previous studies ${ }^{34}$. The MyD88 knockout mouse showed decreased expression of $M y D 88$, likely due the fact that only exon 3 is removed and the primers are not on exon 3.

\section{Tissue harvest and microglial isolation}

Five mice per group were perfused with ice-cold saline and the brain was removed (each group was performed on a different day). The dissected tissue was pooled by treatment within group (ie. all of group 1 saline samples were combined, see Figure S1). Samples were pooled to get enough microglia for both qPCR and western blots. Approximately $1 \%$ of the minced tissue was taken as a total homogenate (TH) sample that includes all cell types. The TH was further divided into $10 \%$ for RNA and $90 \%$ for protein and centrifuged at $1000 \mathrm{x}$ g for 10 minutes at $4{ }^{\circ} \mathrm{C}$. The supernatant was removed and the cells were flash frozen in liquid nitrogen. The remaining sample was used for microglial isolation, as described by Nikodemova et al. $2012^{37}$. Briefly, tissue suspension was enzymatically dissociated using the Neural Tissue Dissociation Kit-Papain (Miltenyi Biotec, Germany) in conjunction with Pasteur pipette manual dissociation. Dissociated tissue was passed through a $70 \mu \mathrm{M}$ strainer (Miltenyi Biotec), centrifuged at $300 \mathrm{x} \mathrm{g}$, and resuspended in $30 \%$ percoll (Sigma-Aldrich, St. Louis, MO, USA). The percoll-cell suspension was centrifuged at $700 \mathrm{x} \mathrm{g}$ for 15 minutes at room temperature, with the myelin fraction removed from the top fraction. Cells were washed and then incubated with CD11b MicroBeads (Miltenyi Biotec) and eluted using MS columns to collect CD11b+ cells. Cells were again divided (10\% for RNA and $90 \%$ for protein) and CD11b+cell pellets were collected by centrifugation at $300 \mathrm{x}$ g for 10 minutes at $4{ }^{\circ} \mathrm{C}$ and then flash frozen. The CD11b- fraction was also spun down and the pellet was resuspended in astrocyte-binding ACSA2 MicoBeads (Miltenyi Biotec). The ACSA2+ fraction was collected as the $\mathrm{CD} 11 \mathrm{~b}+$ fraction was, and the remaining negative fraction (CD11b/ACSA2-) and the astrocyte fraction (ACSA2+) were divided (10\% for RNA, $90 \%$ for protein), spun down and pellets were flash frozen.

\section{RNA isolation and qPCR}

RNA was isolated from all four fractions (TH, CD11b+, ACSA2+, CD11b/ACSA2-) using the MagMax-96 Total RNA Isolation Kit (Thermo Fisher Scientific Inc., Rockford, IL, USA). The RNA yield was quantified on a NanoDrop 1000 spectrophotometer and assessed for quality on an Agilent 2200 TapeStation (Agilent Technologies, Santa Clara, CA, USA). RNA was reverse transcribed into cDNA using the Applied Biosystems High-Capacity cDNA Reverse Transcription Kit (Thermo Fisher Scientific Inc.). cDNA was tested for genomic DNA contamination and showed at least a $10 \mathrm{Cq}$ difference between the $+\mathrm{RT}$ (reverse transcription) and -RT samples ${ }^{38}$. Applied Biosystems TaqMan® Gene Expression Assay (Thermo Fisher Scientific Inc.) primers were used, and specific assay IDs are shown in Table S1. RT-qPCR reactions were performed using SsoAdvanced ${ }^{\mathrm{TM}}$ Universal Probes Supermix (BioRad, Hercules, CA, USA) in $10-\mu \mathrm{L}$ reactions containing $250 \mathrm{pg}$ of cDNA. All reactions were performed in technical triplicates for each biological replicate and included a negative no-template control. Samples were normalized to $18 \mathrm{~s}$ rRNA and relative expression was determined using the CFX software version 3.1 (BioRad).

\section{Protein isolation and western blots}

Cells or tissue were homogenized in lysis buffer $(150 \mathrm{mM} \mathrm{NaCl}, 50$ $\mathrm{mM}$ Tris-HCl pH 7.4, 1 mM EDTA, 1\% Triton-X-100, 1\% sodium deoxycholic acid, $0.1 \%$ SDS, $1 \mathrm{X}$ Halt Protease and Phosphatase Inhibitor Cocktail; Thermo Fisher Scientific Inc.), rocked for 30 minutes at $4^{\circ} \mathrm{C}$, centrifuged for 10 minutes at $10,000 \mathrm{x} \mathrm{g}$, aliquoted, and frozen at $-80^{\circ} \mathrm{C}$. HEK-293 cells were kindly provided by Dr. Mihic's laboratory. These cells were washed with cold PBS, scraped and washed with lysis buffer, and processed as described above. Protein concentrations were determined using the DC Protein Assay (Bio-Rad). Cell lysates (20 $\mu \mathrm{g}$ for fractions, 40 ug for antibody tests) were boiled for 5 minutes, run on $4-15 \%$ Mini-Protean TGX Precast Gels (Bio-Rad), and transferred to PVDF membranes using semi-dry transfer. All fraction blots contained a control sample (mouse whole brain lysate) for normalizing across blots. Membranes were blocked with 5\% dried milk in TBST (Tris-buffered saline with $0.5 \%$ Tween-20) and incubated overnight at $4^{\circ} \mathrm{C}$ with primary antibody (Table S2). Membranes were washed with TBST and incubated with HRP-conjugated secondary antibodies in 5\% dried milk in TBST for 1 hour at room temperature (Table S2). Bands were visualized using Pierce ECL (Thermo Fisher Scientific Inc.) and imaged on film, using G:BOX Chemi XX6 (Syngene, Cambridge, UK). Attempts were made to identify a loading control that was equal across all cell types, but every loading control examined showed differences in expression across fractions.

\section{Combined fluorescent in situ hybridization and immunohistochemistry}

The protocol was adapted from Exiqon miRCURY microRNA ISH Optimization Kit (Exiqon, Vedbaek, Denmark). Mice were transcardially perfused with $4 \%$ paraformaldehyde (PFA), and the brains were post fixed overnight in $4 \%$ PFA at $4^{\circ} \mathrm{C}$ and transferred to $30 \%$ sucrose overnight at $4^{\circ} \mathrm{C}$. Brains were fresh frozen and coronally sectioned on a cryostat (20uM). Free-floating sections were post-fixed in $10 \% \mathrm{NBF}$ overnight at room temperature. After three 1x PBS washes (3 minutes per wash), slices were hybridized with a double DIG-labeled custom Locked Nuclei Acid (LNA) probe (Exiqon) for 1 hour at appropriate hybridization temperature (Table S3). Following hybridization, slices were washed in 5x SSC, 1x SSC (2 times), and 0.2x SSC (2 times) at the same temperature as hybridization for 5 minutes per wash. After a final 0.2x SSC wash at room temperature for 5 minutes, slices were blocked with blocking solution (1x PBS, $0.1 \%$ Tween-20,2\% donkey serum, and 1\% BSA) at room temperature for 15 minutes. Various permeabilization steps were also tested (see source data). Slices were then incubated in anti-DIG antibody (for mRNA probe) and appropriate primary antibody for protein of choice (Table S3) overnight at $4^{\circ} \mathrm{C}$. All antibodies were diluted in antibody solution (1x PBS, $0.05 \%$ Tween-20, 1\% donkey serum, and $1 \%$ BSA). After three $1 \times$ PBS-T $(0.1 \%)$ washes (5 minutes per wash), appropriate secondary antibodies were applied to the slices and allowed to incubate at room temperature for 1.5 hours. 
After three final $1 \times$ PBS washes (10 minutes per wash), slices were mounted on charged slides and counterstained with DAPI (Fluoromount-G, Southern Biotech). Slides were visualized on a Zeiss Axiovert 200M Fluorescent Microscope and analysis was completed on Photoshop CC5 (Adobe). Probe and antibody information is found in Table S3.

\section{Immunohistochemistry}

Brains were prepared as stated above and free-floating sections were placed into PBS. Sections were permeabilized in detergent $(0.1 \%$ Triton-X-100) and blocked in $10 \%$ goat or donkey serum for 1 hour at room temperature. Antibody treatment and mounting was performed as described above. Antibody information is in Table S3.

\section{Statistical methods}

RT-qPCR data was analyzed with a two-way analysis of variance (ANOVA) and Tukey's multiple comparisons test. All statistical analyses were performed using Prism 7 (GraphPad Software, La Jolla, CA). All p-values are shown in Table S4.

\section{Results}

Fraction mRNA cell-type enrichment

Four fractions were collected from the saline and 24-hour LPS treated samples: $\mathrm{TH}$ (total homogenate), $\mathrm{CD} 11 \mathrm{~b}+$ (microglial fraction), ACSA2+ (astrocyte fraction), and CD/AC- fraction (cells remaining after isolation of microglia and astrocytes, referred to as the negative fraction). RT-qPCR was performed using cell-type markers to determine the cell-type enrichment for each of these fractions (Figure 2). Cd11b/Itgam was used as a marker for microglia and expression was found to be highly expressed in the $\mathrm{CD} 11 \mathrm{~b}+$ fraction (enriched 57-fold over TH, $\mathrm{p}<0.0001$ ), lowly expressed in the $\mathrm{TH}$, and absent in the ACSA2+ and CD/ACfractions (Figure 2A). Glast/Slcla3 was used as an astrocyte marker and was found to be lowly expressed in the TH, highly expressed in the ACSA2+ fractions under saline conditions (enriched 8-fold over TH, p $<0.0001$ ), and absent in the CD11b+ and CD/AC- fractions (Figure 2B). Neun was used as a neuronal marker and was expressed at high levels in the $\mathrm{TH}$, low levels in the CD/AC- fraction (0.02-fold compared to $\mathrm{TH}, \mathrm{p}<0.0001)$, and expression was absent in the CD11b+ and ACSA2+ fractions (Figure 2C). The reason for the lack of neuronal markers in the negative fraction is that adult neurons don't usually survive the isolation procedure; therefore, the $\mathrm{TH}$ taken before isolation contains the most neurons. Tek was used as a marker for endothelial cells and was highly expressed in the CD/AC- fraction (15-fold over TH, p < 0.0001) and lowly expressed in the TH, $\mathrm{CD} 11 \mathrm{~b}+$ fraction and ACSA2+ fraction (Figure 2D). Tek expression decreased significantly in the $\mathrm{CD} / \mathrm{AC}$ - fraction following LPS (0.2-fold, p < 0.0001). Cd68 was used as a marker of activated microglia and was highly expressed in the CD11b+ fraction and increased following LPS treatment $(1.8$-fold, $p<0.0001)$ (Figure 2F).

\section{TIr mRNA cell-type localization and LPS response}

qPCR was used to evaluate the expression of the most widely studied Tlrs; Tlr2, Tlr3, Tlr4, and the TLR4 co-receptor, Cd14. Under basal conditions, expression of Tlr2, Tlr4 and Cd14 was primarily localized to microglia, as evidenced by the high SAL-CD11b+ expression compared to SAL-TH expression (expression in $\mathrm{Cd} 11 \mathrm{~b}+$ fraction over TH: Tlr2 41-fold, $\mathrm{p}=0.001$; Tlr4 25-fold, $\mathrm{p}<0.0001$; Cd14 75-fold, $\mathrm{p}<0.0001$ ) (Figure 3). In response to LPS, Tlr2 and Cd14 expression increased in microglia 4-fold $(\mathrm{p}<0.0001)$ and 2.6-fold ( $\mathrm{p}<0.0001$ ), respectively (Figures $3 \mathrm{~A}$ and D). Alternatively, Tlr4 expression decreased by approximately $50 \%$ in microglia following LPS $(\mathrm{p}<0.0001$ ) (Figure 3C). In contrast to Tlr2, Tlr4 and Cd14, Tlr3 was expressed in all fractions, with highest expression in astrocytes (8-fold enrichment over $\mathrm{TH}$, $\mathrm{p}<0.0001)$. In response to LPS, Tlr3 expression increased in astrocytes $(1.5$-fold, $\mathrm{p}=0.0007)$, but not in any of the other fractions (Figure 3B). No $T l r$ expression changes were detected in the total homogenate.

\section{MyD88-dependent pathway mRNA localization and LPS response}

To determine localization and LPS response, mRNA expression of components of the MyD88-dependent pathway (Myd88, Irak1, Irak4, Traf6, and $I k k b)$, as well as cytokines produced in response to MyD88-pathway activation (Illb, Il6, Tnf) were measured (Figure 4). While all MyD88-dependent pathway genes were expressed highest in microglia under basal conditions, the expression patterns were variable. Myd88 and Irak4 displayed low basal expression in other fractions, while Irakl, Traf6, and Ikkb were expressed at greater than $50 \%$ of the expression level of microglia, suggesting expression in astrocytes and endothelial cells as well (Figures 4A-E). In contrast, the cytokines were almost exclusively expressed in microglia (Figures 4F-H). In response to LPS, Myd88 expression increased in microglia $(1.4$-fold, $\mathrm{p}=0.0062)$ while Irak4 decreased (0.64-fold, $\mathrm{p}=0.0023$ ) (Figures $4 \mathrm{~A}$ and $\mathrm{C}$ ). Interestingly, Traf6 increased in astrocytes $(2.1$-fold, $\mathrm{p}=0.0005)$ and the $\mathrm{CD} / \mathrm{AC}$ - fraction (2.1-fold, $\mathrm{p}=0.004$ ), while Irakl trended towards an increase in astrocytes ( $\mathrm{p}=0.02$ in t-test, but not significant when corrected for multiple comparisons) (Figures 4B and D). Both $I l 1 b$ and Tnf increased in microglia following LPS administration, with Tnf increasing almost 14-fold (Figures 4F and H). In contrast, Il6 expression did not increase in microglia, but trended towards an increase in astrocytes and the $\mathrm{CD} / \mathrm{AC}$ - fraction (Figure 4G; $\mathrm{p}=0.04$ astrocytes and $\mathrm{p}=0.03 \mathrm{CD} / \mathrm{AC}$-, uncorrected $\mathrm{t}$-test).

\section{TRIF-dependent pathway mRNA localization and LPS response}

Expression of TRIF-dependent pathway components (Trif, Traf3, Ikki, Irf3) and outputs (Ifnb, Ccl5, Cxcl10) were measured under basal conditions and in response to LPS to allow comparison with the MyD88-dependent pathway (Figure 5). Trif and Irf3 had similar basal expression profiles with highest expression in microglia (Trif 5-fold enriched over TH, p < 0.0001; Irf3 4-fold enriched over TH, p < 0.0001), but Irf3 was enriched in both the astrocyte and negative fractions (3-fold enrichment in astrocyte fraction, $\mathrm{p}=0.01 ; 2$-fold enrichment in negative fraction over $\mathrm{TH}, \mathrm{p}=0.02$ ), while Trif showed only modest expression in all fractions (Figures 5A and D). Traf3 and Ikki were expressed relatively evenly across the fractions under basal conditions, although $I k k i$ trended towards highest expression in astrocytes ( $\mathrm{p}<0.0001$ using 1-way ANOVA for saline group) (Figure 5B and C). Under basal conditions, Ifnb, Ccl5, and CxcllO are virtually 
A

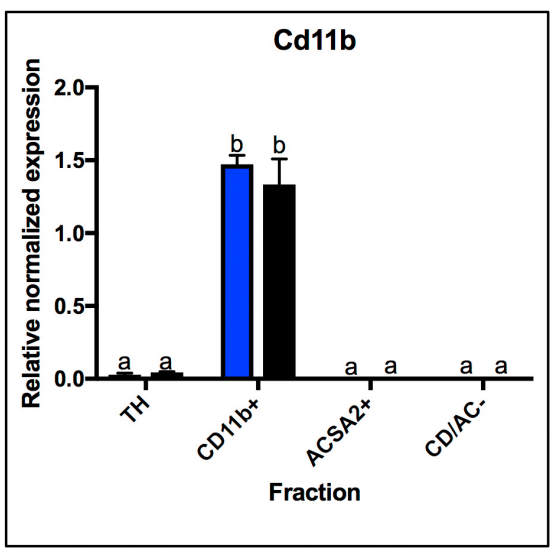

D

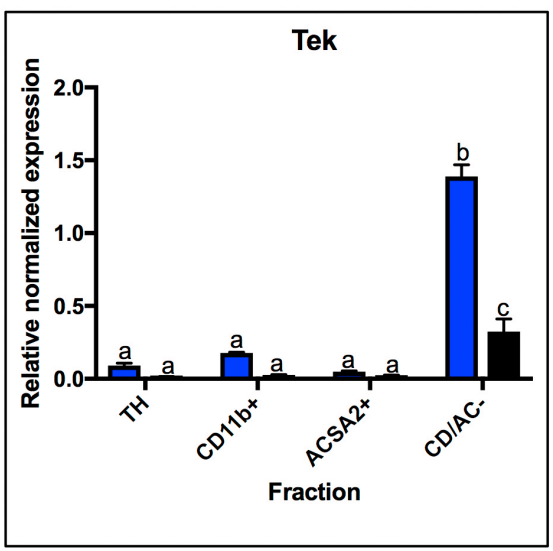

B

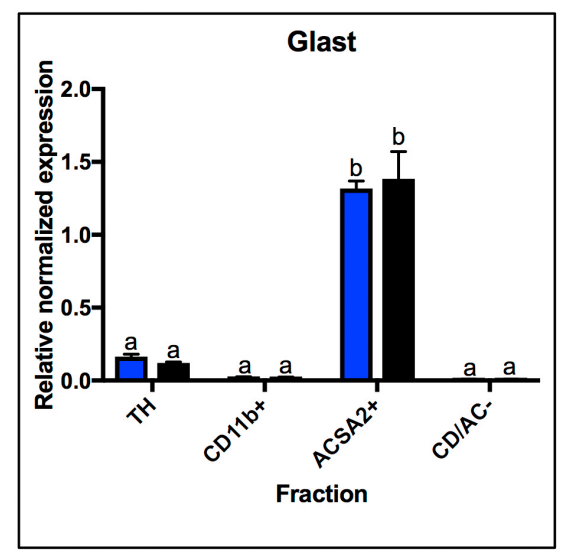

E

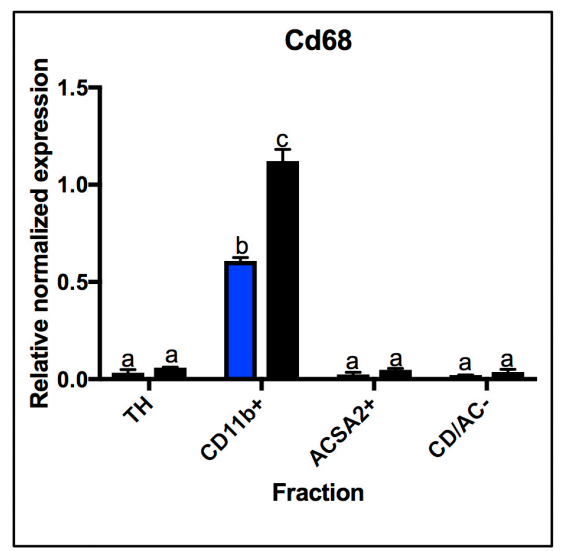

C

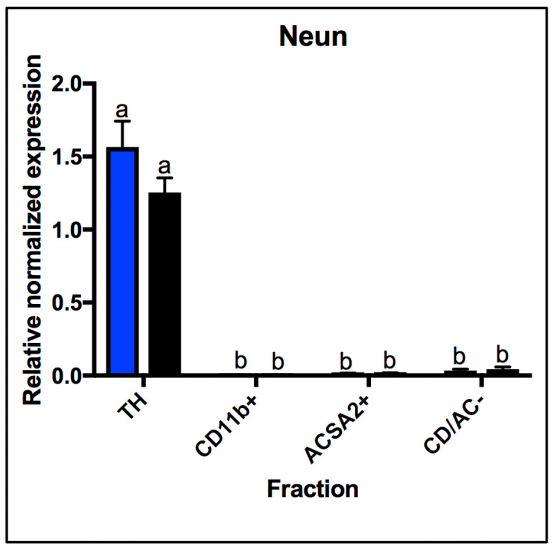

Figure 2. Cell-type marker mRNA expression. qPCR analysis of cell-type marker expression in the four fractions. A. The microglial fraction was highly enriched for the microglial marker $\mathrm{Cd11b}$, and Cd11b was absent in the astrocyte and negative fraction. B. The astrocyte fraction was highly enriched for the astrocyte marker Glast, and expression of Glast was extremely low or absent in the microglial and negative fractions. C. The total homogenate (TH) had high expression of the neuronal marker Neun. Neun was absent from the microglial and astrocytes fractions and was expressed in low levels in the negative fraction. D. The endothelial cell marker Tek was highly expressed in the negative fraction and lowly expressed in the other three fractions. Tek expression decreased with LPS in the negative fraction. E. The activated microglial marker Cd68 was highly expressed in the microglial fraction, and lowly expressed in the other fractions. Cd68 expression increased with LPS in the microglial fraction. Two bars with the same letter are not statistically different; two bars with no letter in common are statistically different (two-way ANOVA with Tukey's test for multiple comparisons, p<0.05). SAL, saline; LPS, liposaccharide.

undetectable in all fractions, except for some $C c l 5$ expression in microglia and some $\mathrm{Cxcl10}$ expression in microglia and astrocytes (Figures 5E-G). In response to LPS, Trif and Irf3 expression decreased in microglia (Trif 0.73-fold, $\mathrm{p}=0.02$; Irf3 0.79-fold, $\mathrm{p}=0.0138$ ), while Traf3 expression decreased in the $\mathrm{TH}$ (0.62-fold, $\mathrm{p}=0.03)$. In contrast, Ikki showed 23.5-fold increase in expression following LPS ( $\mathrm{p}<0.0001$ ). Like Ikki, Ifnb and Ccl5 increased in microglia (Ifnb only detected after LPS, Ccl5 37-fold increase, $\mathrm{p}<0.0001$ ), while $\mathrm{Cxcl10}$ trended towards an increase in microglia and astrocytes (microglia 39-fold, $p=0.047$ uncorrected T-test; astrocytes 25 -fold, $\mathrm{p}=.045$ uncorrected T-test).
Antibody validation in knockout tissue and HEK-293 cells Knockout mice for TLR2, TLR4, and MyD88 were available in the lab and used to test the specificity of antibodies for those proteins (Figure 6). In addition, HEK-293 cell lysates were used for validation because these cells should not express TLR2, TLR3, TLR4, or IL-1 $\beta$ (www.proteinatlas.org) ${ }^{26}$. Testing with the TLR2 antibody revealed expression in wild-type brain tissue, HEK-293 cells, and TLR2 knockout tissue, suggesting non-specific binding (Figure 6A). The TLR3 antibody showed strong expression (although at a lower molecular weight than expected) in the WT brain tissue and no expression in the 293 cells (Figure 6B). Two TLR4 antibodies 
A
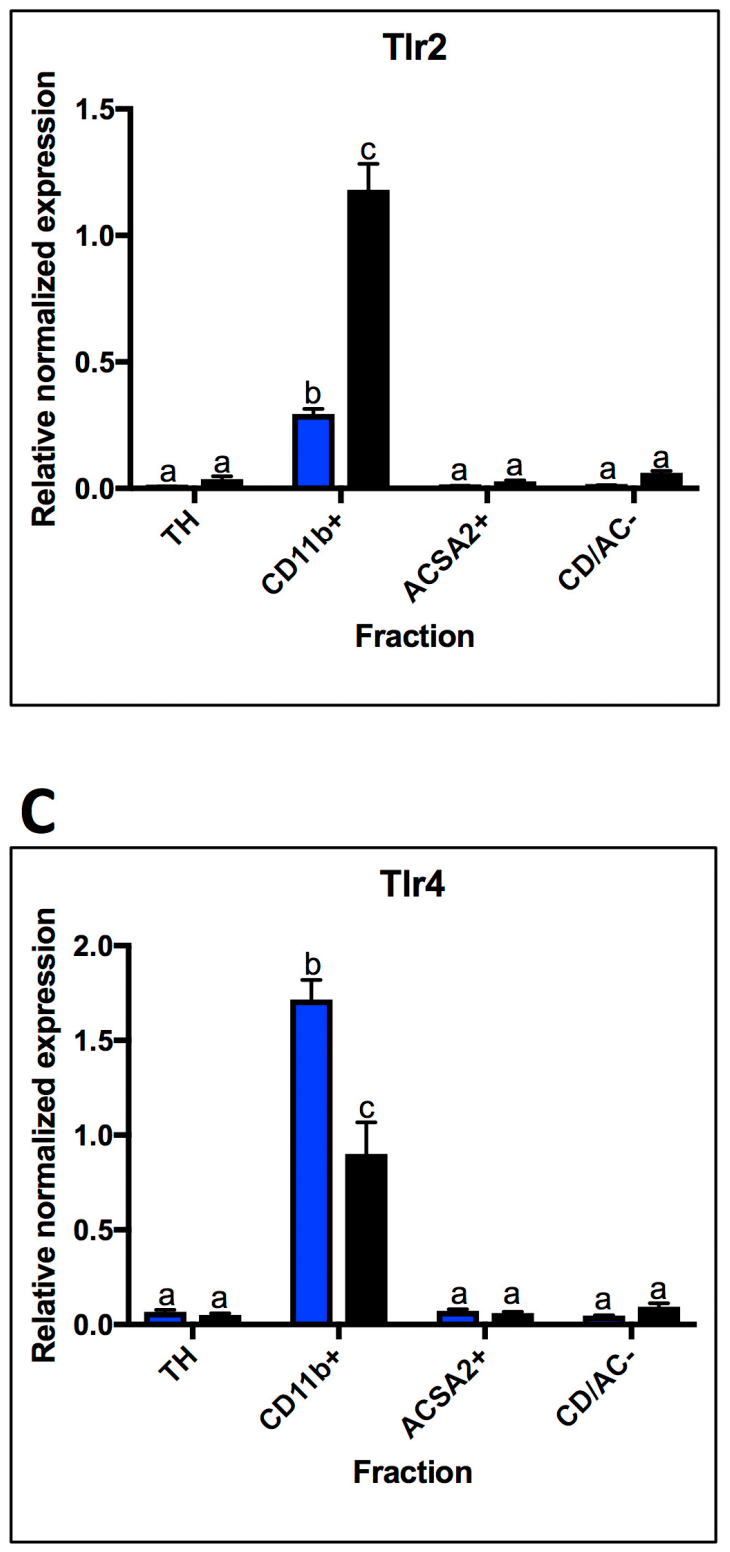

B
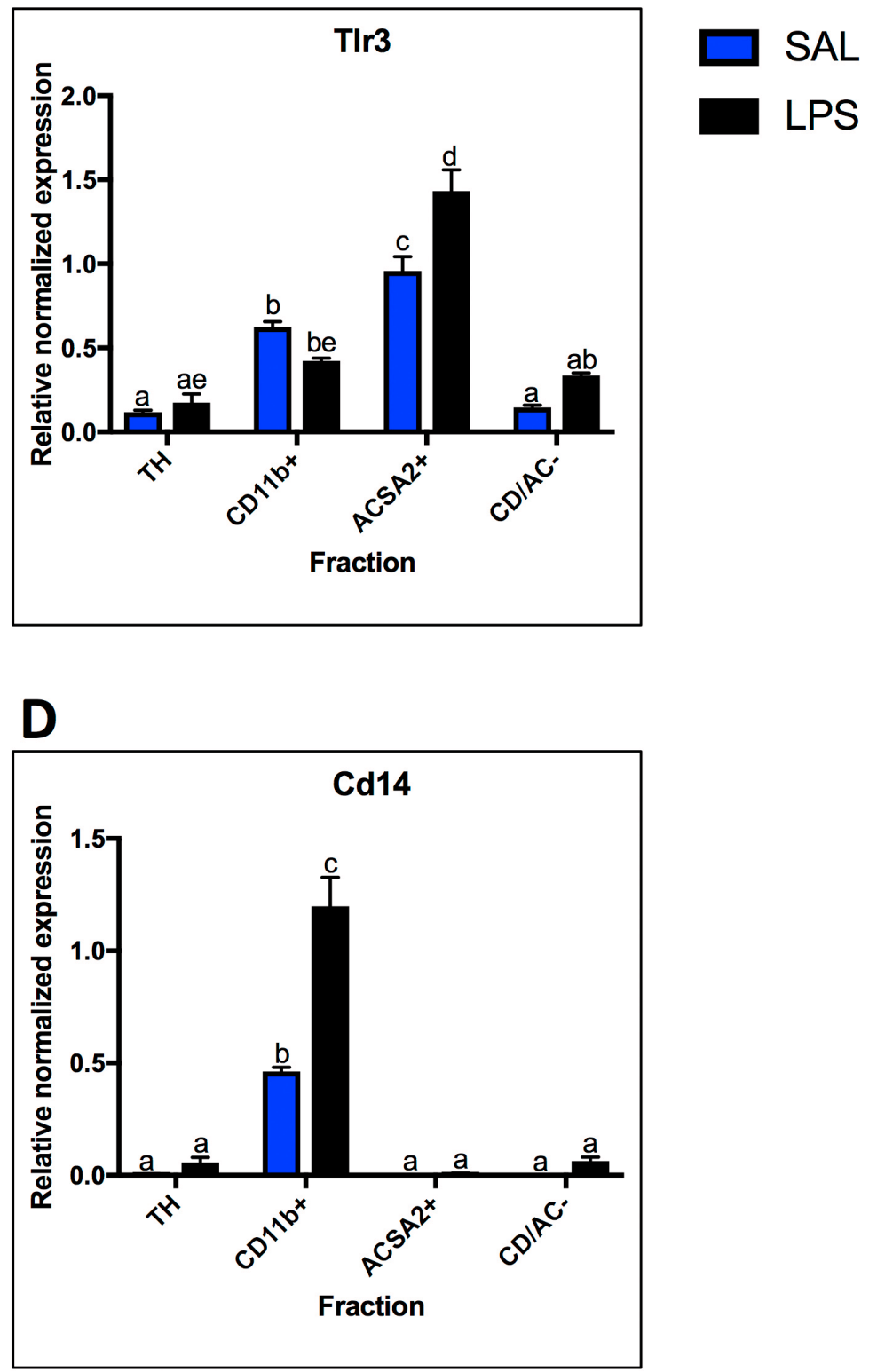

Figure 3. Toll-like receptor (TLR) mRNA expression. Fraction localization and LPS expression changes for TLRs and co-receptors measured by qPCR. A. TIr2 is expressed primarily in the microglial fraction and expression increases with LPS. B. TIr3 is enriched in both microglia and astrocytes compared to the total homogenate (TH), with higher expression in astrocytes. Astrocyte TIr3 expression increased with LPS. C. TIr4 expression is highly microglial and decreases following LPS. D. Cd14 is highly enriched in microglia and increases with LPS. Two bars with the same letter are not statistically different; two bars with no letter in common are statistically different (two-way ANOVA with Tukey's test for multiple comparisons, $p<0.05)$. SAL, saline; LPS, liposaccharide.

were tested and both produced signals in the 293 lysates and in the TLR4 knockout tissue (Figures 6C and D). Furthermore, the TLR4 (76B357.1) antibody appeared to run at a lower molecular weight than anticipated, though there were multiple bands that appeared at different molecular weights in each lysate (Figure 6C). The IL-1 $\beta$ antibody produced a strong signal in the 293 lysates, suggesting it is also non-specific (Figure 6E). Five MyD88 antibodies from two different companies were tested in MyD88 knockout tissue (Figures 6F-J). All 5 antibodies produced a signal in the knockout tissue, and sc-74532 appeared at the incorrect molecular weight, indicating that none of these antibodies were specific. These tests suggested that most of the antibodies that we tested were nonspecific, and made us skeptical of the ones we could not test in knockout tissue. Responses from the antibody vendors indicated 
A

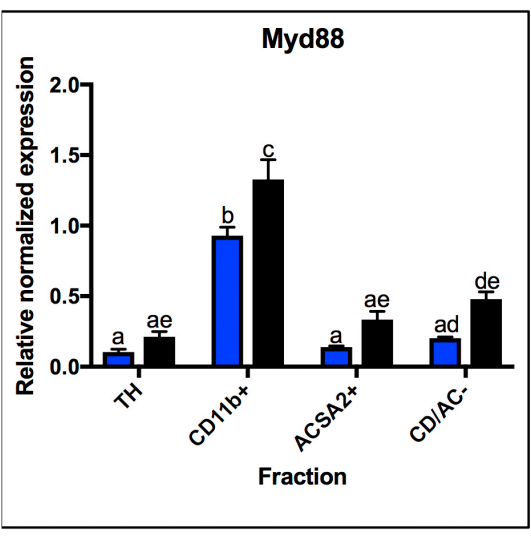

B

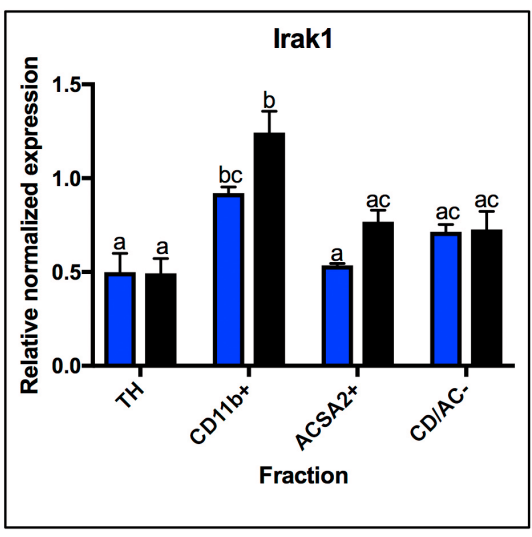

E

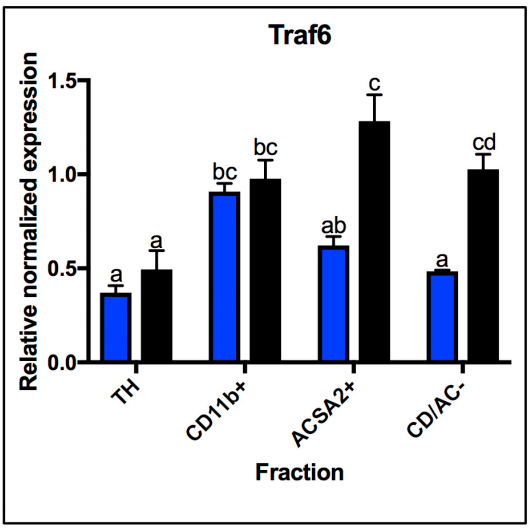

$\mathbf{F}$

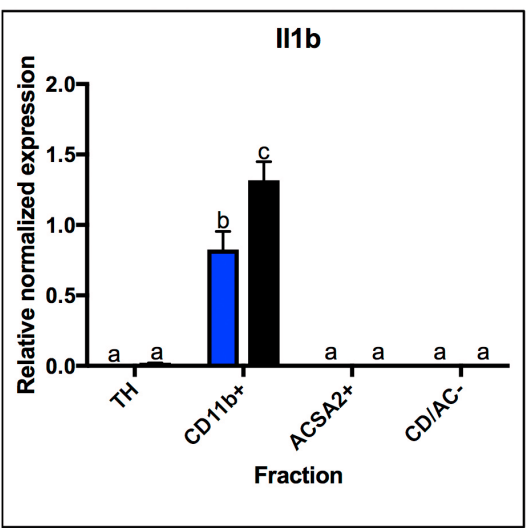

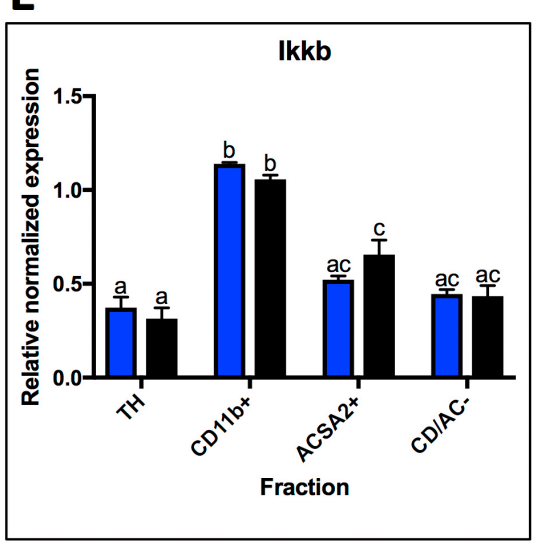

G

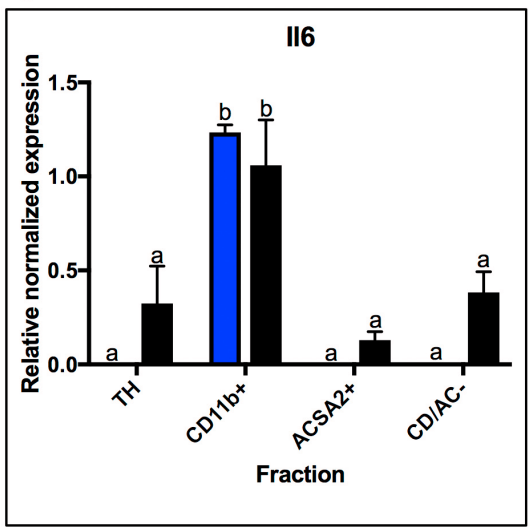

C

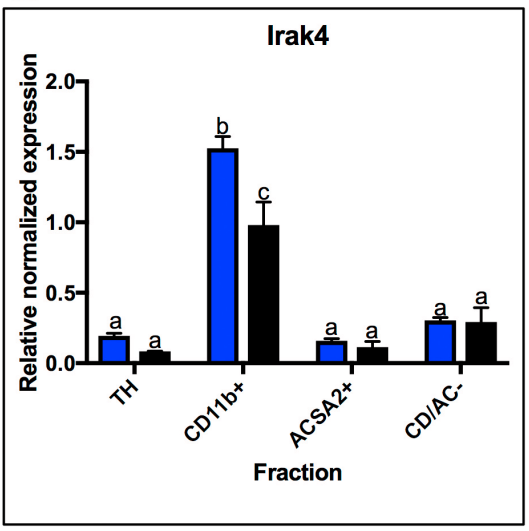

$\square$ SAL

LPS

Figure 4. MyD88-dependent pathway mRNA expression. Fraction localization and LPS expression changes for components and outputs of the MyD88-Dependent Pathway, measured by qPCR. A. MyD88 is highest enriched in the microglial fraction and increases with LPS. B. Irak1 is highest enriched in the microglial fraction, but present in moderate levels (expression is 50\% or more than that of microglia) in all other fractions. Irak1 expression increases in microglia with LPS. C. Irak4 expression is highly enriched in microglia under basal conditions, and decreases in microglia after LPS. D. With saline, Traf6 is enriched in the microglial fraction, but present in moderate levels in all other fractions. With LPS, Traf6 expression increases in the astrocyte fraction and the negative fraction. E. Ikkb expression was highest in microglia, but expressed in moderate levels in all other fractions. No significant expression changes were seen after LPS treatment. F. Expression of $\| 1 \mathrm{~b}$ is only detected in microglia and increases with LPS. G. Expression of $/ / 6$ is only detected in microglia with saline, but is detected in all other fractions after LPS. H. Tnf was only detected in the microglial fraction and increased following LPS. Two bars with the same letter are not statistically different; two bars with no letter in common are statistically different (two-way ANOVA with Tukey's test for multiple comparisons, $\mathrm{p}<0.05)$. SAL, saline; LPS, liposaccharide; TH, total homogenate. 
A

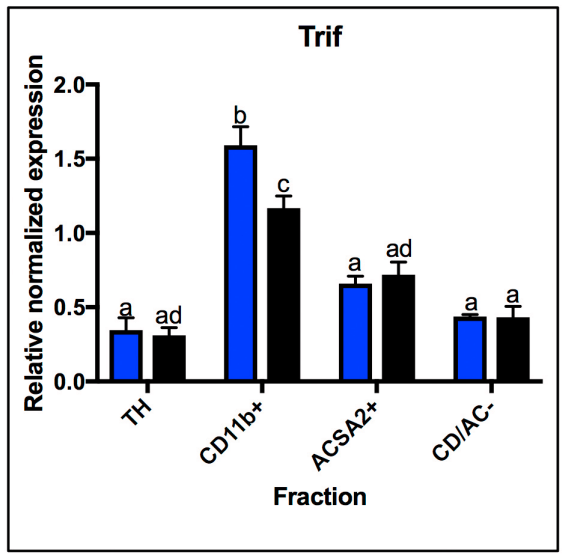

C

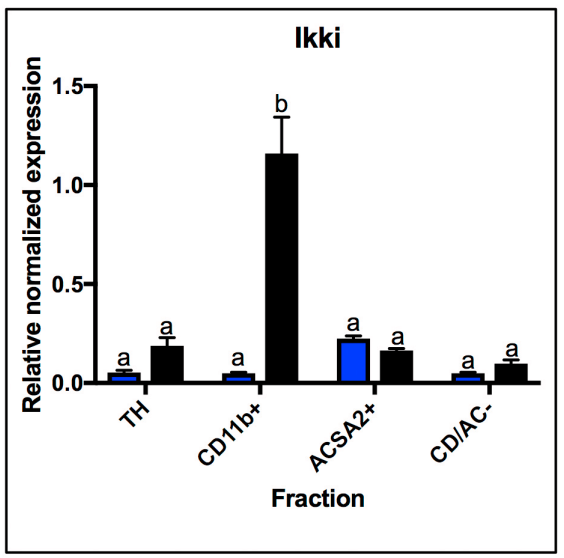

E

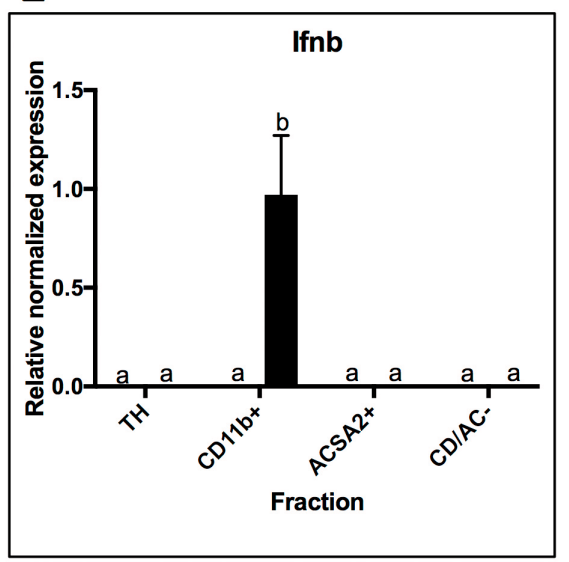

B

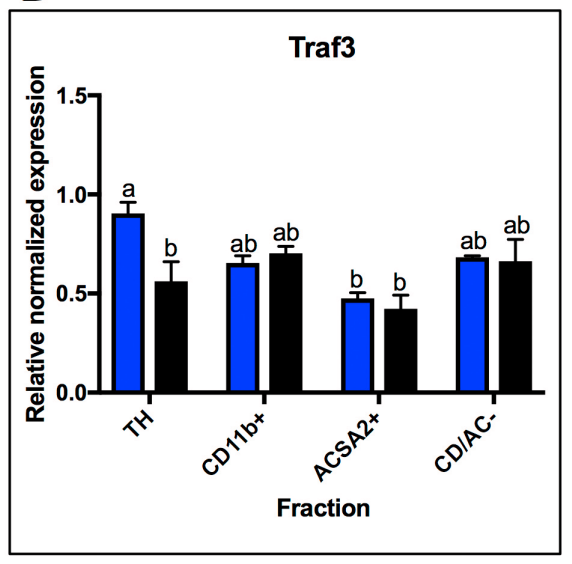

D

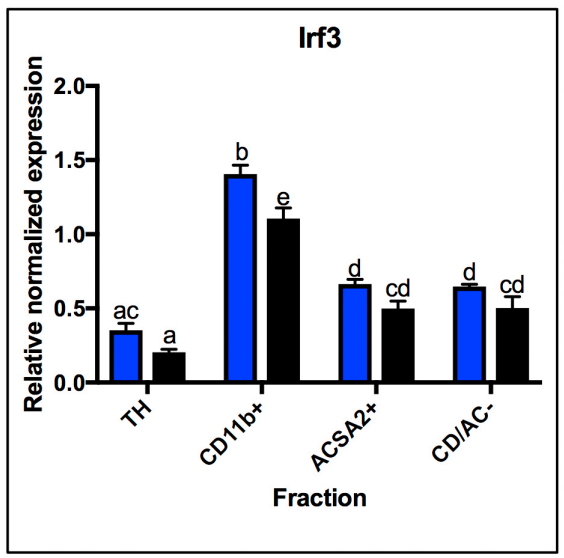

F

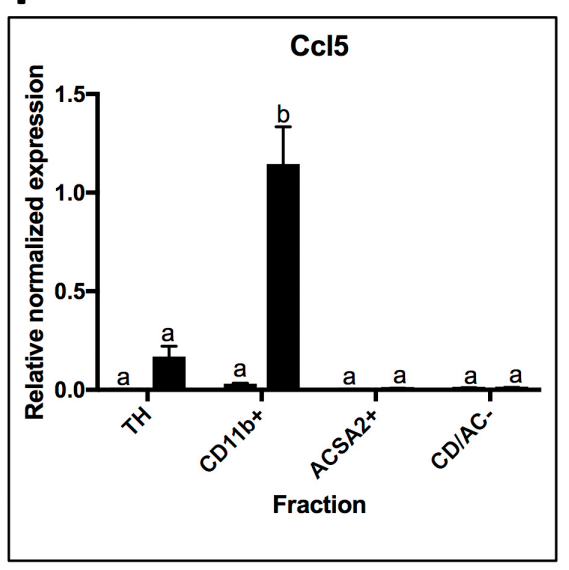

G

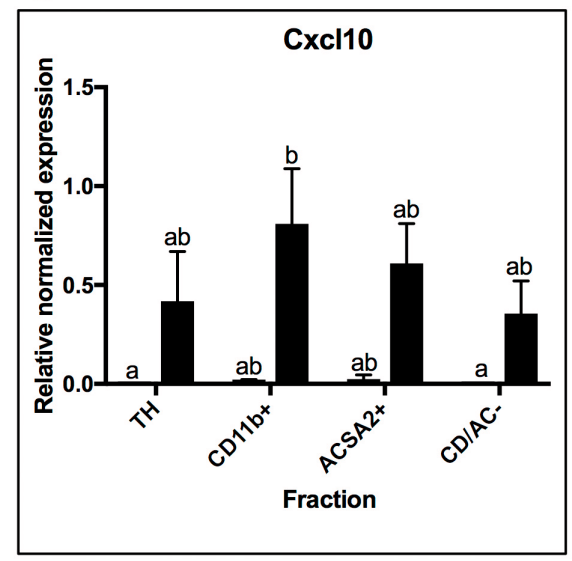

Figure 5. TRIF-dependent pathway mRNA expression. Fraction mRNA localization for components and outputs of the TRIF-Dependent Pathway in saline and LPS treated animals. A. Trif was highest expressed in the microglial fraction with saline and decreased with LPS. B. Traf3 expression was relatively even across the fractions, with only significant difference being between the total homogenate (TH) and the astrocyte fraction. There were no significant changes with LPS. C. Ikki expression was not significantly enriched in any fraction with saline, but was highest in astrocytes. With LPS, expression increased in the microglial fraction. D. Irf3 expression was highest in the microglial fraction, but was also significantly enriched over the TH in the astrocyte fraction and negative fraction. E. Ifnb was not detected in any fractions with saline, but was expressed in microglia with LPS. F. Expression of Ccl5 was expressed in low amounts in microglia with saline, but was detected in the TH with LPS and increased in microglia. G. Cxc/10 was expressed in low levels in the microglial and astrocyte fractions with saline, but was detected in all fractions with LPS, although none of the changes were significant. Two bars with the same letter are not statistically different; two bars with no letter in common are statistically different (two-way ANOVA with Tukey's test for multiple comparisons, $\mathrm{p}<0.05)$. SAL, saline; LPS, liposaccharide. 
A. TLR2 (sc-10739)

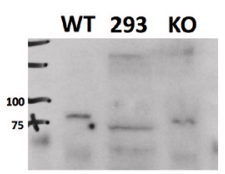

D. TLR4 (sc-293072)

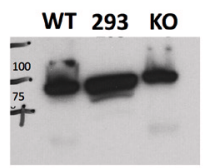

G. MyD88 (sc-8197)

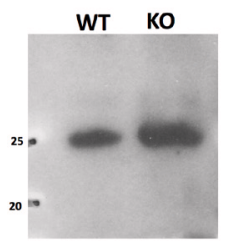

\section{J. MyD88 (ab2068)}

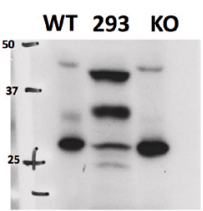

B. TLR3 (Enzo)

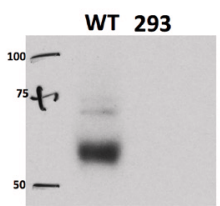

E. IL-1ß (sc-7884)

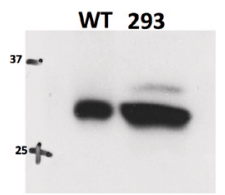

H. MyD88 (sc-74532)

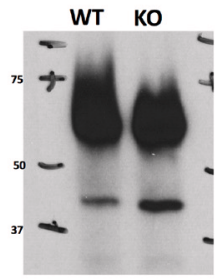

C. TLR4 (76B357.1)

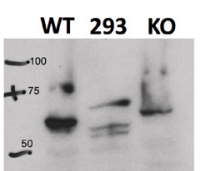

F. MyD88 (sc-11356)

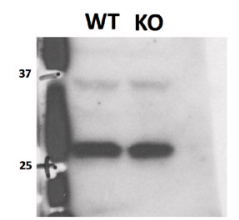

I. MyD88 (ab2064)

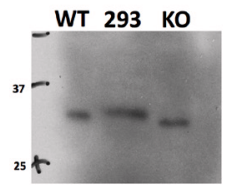

Figure 6. Antibody validation. Antibody tests in negative controls (knockout tissue and HEK-293 cells). Each antibody was run once with just knockout tissue if available, and once with knockout tissue and HEK 293T cell lysates. A. The TLR2 antibody produces a signal in HEK-293 cells and TLR knockout tissue (KO), neither of which should express TLR2. B. The TLR3 antibody only produced signal in the WT tissue. C and D. Both TLR4 antibodies produced signals in the HEK-293 cells and the TLR4 knockout tissue, neither of which should express TLR4. E. The IL-1 $\beta$ antibody produced a signal in the HEK-293 cells, which should not express IL-1 $\beta$. F-J. All five MyD88 antibodies produced a signal in the MyD88 knockout tissue.

that antibodies were never tested against negative controls, only against blocking peptides.

\section{Fraction protein localization in western blots}

Because antibody specificity could not be verified, full replicates of western blots were not performed, and thus not quantified. However, sample western blot images for each antibody are shown in Figure 7 to demonstrate the variety of expression profiles and how different antibodies to the same protein produce different results. First, as with qPCR, cell-type marker expression was evaluated in the lysates using antibodies for NEUN (neuronal marker), GFAP (astrocyte marker), and IBA1 (microglial marker) (Figure 7A). Differences in markers between $\mathrm{qPCR}$ and western blots were due to antibody availability and efficacy. Consistent with the qPCR data, NEUN was present in high amounts in the control sample and the total homogenate sample, but not in other fractions. GFAP was expressed in the control sample and the TH, but expressed highest in the astrocyte fraction, also consistent with the qPCR results. IBA1 was expressed very strongly in microglia and could be seen in the control and TH after a much longer exposure that left the microglial expression overexposed. These findings are consistent with the qPCR data which shows that expression of microglial markers is over 50x higher in the microglial fraction than the TH.

Despite the determination that many of the antibodies were nonspecific, localization of TLR protein and IL-1 $\beta$ was investigated to see if these results mirrored some of the confusing data in the literature suggesting non-microglial localization (Figure 7B). Even though Tlr2 mRNA expression was predominantly microglial, TLR2 protein was detected in every fraction except 


\section{A. Cell type markers}

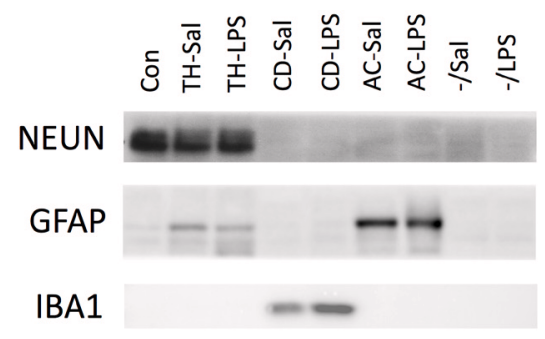

C. MyD88

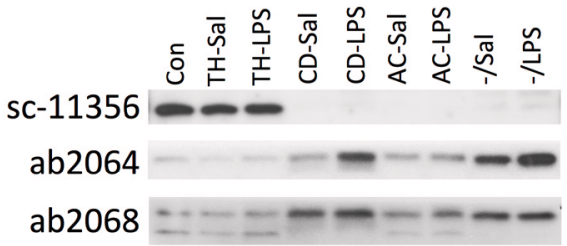

\section{E. TRAF6}
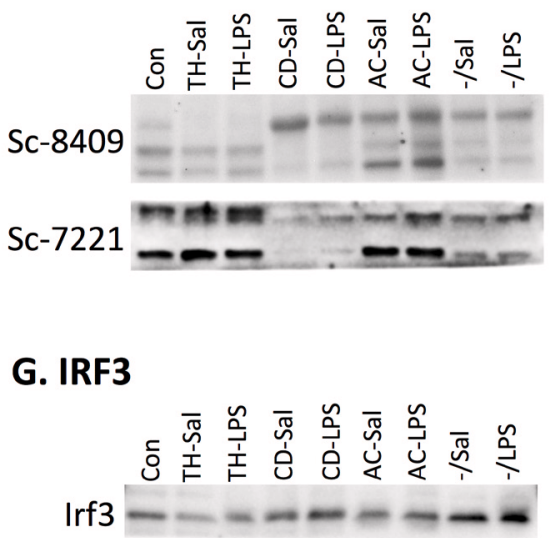

\section{B. TLRs and IL1 $\beta$}

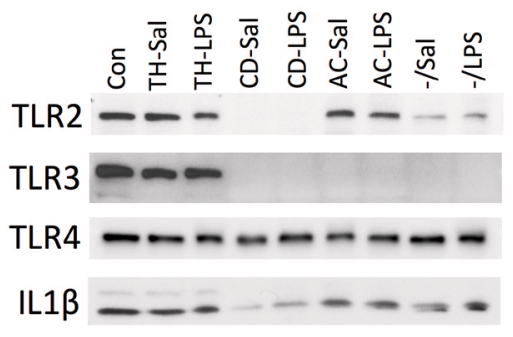

D. IRAKS

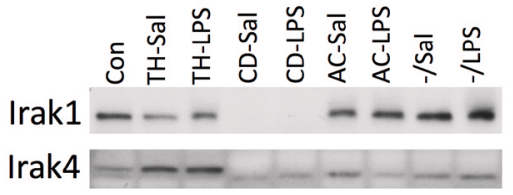

\section{H. IKK $\varepsilon$}

F. IKK $\beta$

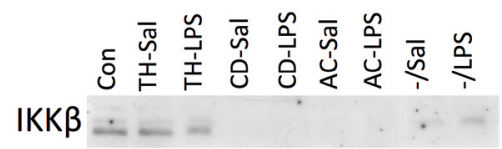

Figure 7. Protein expression in fractions. Fraction protein expression in representative western blot images. Number of experiments for each antibody are indicated in parenthesis. A. Cell-type specific antibodies verify cell-type enrichment in the fractions. NEUN, a neuronal marker, is expressed in the control sample and the total homogenate $(\mathrm{TH})(\mathrm{n}=3)$. GFAP, an astrocytic marker, is expressed in low levels in the TH and higher levels in astrocytes $(n=2)$. IBA1, a microglial maker, is expressed in microglia $(n=3)$. B. Expression for TLR2 appears to be in all fractions except microglia $(n=3)$, while TLR3 is only detected in the TH $(n=2)$, and TLR4 $(n=2)$ and IL-1 $(n=3)$ are detected in all fractions C. Blotting with three different MyD88 antibodies produced different results ( $n=3$ for each). Sc-11356 suggested MyD88 is only expressed in the total homogenate, while ab2064 and ab2068 show expression in all fractions, with highest expression in microglia and the negative fraction. D. IRAK1 $(n=2)$ shows expression in all fractions except microglia and IRAK4 $(n=3)$ shows expression in all fractions, but highest expression in the TH. E. Two different TRAF6 antibodies produce multiple bands and different results. Based on predicted molecular weight, both antibodies show highest expression in the TH and lowest expression in microglia ( $n=2$ for each). $\mathbf{F}$. IKK $\beta$ showed expression in the TH and light expression in the negative fraction $(n=2)$. G. IRF3 was detected in all fractions, but highest in the negative fraction. $\mathbf{H}$. Two antibodies were used to evaluate IKKE. Sc-5693 gave signal only in the TH while Sc-376114 produced signal in all cell types ( $n=3$ for each). Sal, saline; LPS, liposaccharide; CD, CD11b+; AC, ACSA2+.

microglia. TLR3, which was found to be microglial and astrocytic on the mRNA level, was found exclusively in the TH on the protein level, suggesting neuronal localization. TLR 4 and IL1 $\beta$ were highly expressed in microglia on the mRNA level, but were expressed in all fractions on the protein level. Furthermore, IL-1 $\beta$ expression was lowest in microglia. These data suggest that studies detecting neuronal localization of TLRs, despite microglial mRNA, may be due to non-specific antibodies.

Because we had so many antibodies that claimed to detect MyD88, this presented an opportunity to compare localization of the same protein using different antibodies (Figure 7C). MyD88 (sc-11356) 
was expressed only in the $\mathrm{TH}$, suggesting neuronal expression. In contrast, ab2064 and ab2068 were expressed in all fractions, although highest in microglia and in the negative fraction. MyD88 (sc-8197) gave such strange results with vastly different molecular weight bands across the fractions, that it was not included. MyD88 (sc-74532) was not used because tests revealed that the signal was at the wrong molecular weight (Figure $6 \mathrm{H}$ ). These results were particularly concerning because every antibody tested in the knockout was non-specific and different antibodies produced different results.

The rest of the MyD88-pathway produced equally confusing results. Like TLR2, IRAK1 protein was expressed in every fraction except microglia. TLR4 showed highest expression in the $\mathrm{TH}$, but faint expression in other fractions at a slightly lower molecular weight. For TRAF6, we had two antibodies from the same company, sc-8409 (monoclonal mouse) and sc-7221 (rabbit polyclonal). Both antibodies produced several bands (Figure 7E), making it difficult to determine what signal was real. TRAF6 should run at $60 \mathrm{kD}$, which corresponds to the middle band on the sc- 8409 blot and top and on the sc- 7221 blot. Based on these bands, expression appears to be highest in the TH and the astrocyte fraction. IKK $\beta$ was primarily localized to the TH (Figure 7F), which is consistent with the neuronal localization seen in immunohistochemistry data from our $\operatorname{lab}^{39}$, but inconsistent with the qPCR data.

Protein expression evaluation was limited for the TRIF-dependent pathway (due to antibody challenges) and only expression of IRF3 and IKK $\varepsilon$ was determined (Figure $7 \mathrm{G}$ and $\mathrm{H}$ ). IRF3 was expressed in all fractions, but highest expression was in the negative fraction. IKK $\varepsilon$ was evaluated using two antibodies, sc-5693 (goat polyclonal) and sc-376114 (mouse monoclonal). IKKe sc-5693 is a very weak antibody, but detected some protein in the control sample and total homogenate (the bands in the astrocyte fraction are suspected to be bleed through). IKK $\varepsilon$ (sc-376114) is supposed to be expressed at $80 \mathrm{kD}$, which corresponds to the top band; however, the multiple bands raise concerns.

\section{Protein and RNA expression in tissue sections}

Several of the proteins evaluated with western blot have also been investigated in brain tissue using immunohistochemistry with the same or different antibodies. Examples of these are shown in Figure S4. Immunohistochemistry reveals highly neuronal expression in tissue for MyD88 (sc-8197), IRAK1 (sc-7883), and TRAF6 (sc-7221). These results are relatively consistent across TLR-pathway antibodies that have been tested in our lab (high neuronal staining). Interestingly, attempts to look at Irf3 mRNA expression via in situ hybridization also suggested neuronal localization (Figure S5). Because we knew that Irf3 mRNA should be in microglia, we tested a microglial marker, Tmem11940, using the same in situ protocol. Tmem119 also failed to express in microglia (Figures S5C and D), suggesting that there may be a permeability issue when targeting glial cells in tissue, resulting in high background staining in neurons. It is worth noting that $\operatorname{Irf} 3$, which is more heterogeneous across cell types, showed a much stronger neuronal signal than Tmem119, which should only be in microglia. This suggested to us that the small amount of Irf3 localized in neurons was all we could detect, while the detected neuronal Tmem119 was just background due to increased probe concentrations.

Dataset 1. Dataset containing the following six files: ISH localization images, ISH images, knockout animal qPCR, Sal-LPS qPCR data, Sal-LPS western blots and validation western blots

http://dx.doi.org/10.5256/f1000research.12036.d168396

\section{Discussion}

TLR signaling is a key component of the innate immune response and it contributes to many brain disorders, including alcohol use disorders. However, the cell-type specific response to immune stimuli in the CNS remains unclear. Identification of the cell-type localization of TLR signaling and immune response within the brain is necessary to elucidate the functional implications of perturbed signaling and to design future studies with in vivo manipulations. To address this, we used isolated glial cells from adult mice that had been administered either saline or LPS. Using four distinct cell-fractions, we evaluated the mRNA expression of TLRs, their downstream signaling molecules, and the transcriptional outputs of their signaling (Table 1; Figure 8). In addition, we tried to profile the protein expression of TLR signaling molecules. Unfortunately, we were not able to draw any conclusions about the protein localization, but we have identified reasons why there may be disagreement in the field.

Although expression of mRNA from the TLR signaling pathway was primarily microglial as expected, there were extremely variable expression profiles within the pathways. This is consistent with gene expression data from adolescent (P17) mice in the RNA-Seq transcriptome database ${ }^{25}$. While expression of Tlr2, Tlr4, and Cd14 were highly microglial, expression of Tlr3 was highest in astrocytes, where expression increased in response to LPS. These findings are consistent with several studies that have shown Tlr3 to be expressed and functional in astrocyte ${ }^{15,16,41,42}$, as well as a study that shows in vitro LPS increases Tlr3 expression in primary astrocyte cultures while decreasing Tlr3 expression in primary microglial cultures $^{18}$. TLR3 signals through the TRIF-dependent pathway; however, the components of the TRIF-dependent pathway showed varied expression and LPS responses. This raises the question of how signaling molecules within one pathway could be expressed in different cell types. Although Trif and Irf3 expression is highest in microglia, there is still significant expression in astrocytes, and Ikki expression trends towards being mostly astrocytic under basal conditions. Therefore, it is possible that signaling is occurring in both cell-types and that the mRNA expression of the receptor and its signaling molecules are not 1:1 within the cell. Furthermore, microglial Trif and Irf3 expression decrease following LPS, while Ikki expression increases, suggesting they are independently regulated. This is supported by the involvement of Ikki in other LPSresponsive pathways (e.g. JAK/STAT signaling), which could have different cell-type specificity. 
Table 1. Summary of qPCR data. Summary of 24 hour LPS qPCR data. Colors indicate fraction: microglial, teal; astrocyte, yellow; negative fraction, orange. Primary localization with saline (SAL) is determined by fraction enrichment compared to the total homogenate (TH) under saline conditions, with fold-enrichment shown in the next column. Primary localization with liposaccharide (LPS) is determined by fraction enrichment compared to the TH with LPS treatment, with fold change shown in the next column. Change in each fraction with LPS is determined by comparing expression in that fraction with SAL to expression in that fraction with LPS, with direction and fold-change noted. Red indicates increased expression, while blue indicates decreased expression. Only significant differences are noted $(p<0.05$, two-way ANOVA with Tukey's multiple comparisons test). CD, Cd11b+; AC, Acsa2+.

\begin{tabular}{|c|c|c|c|c|c|c|c|c|}
\hline Gene & $\begin{array}{c}\text { Primary } \\
\text { localization } \\
\text { with SAL }\end{array}$ & $\begin{array}{c}\text { Fold } \\
\text { enrichment } \\
\text { over TH (SAL) }\end{array}$ & $\begin{array}{c}\text { Primary } \\
\text { localization } \\
\text { with LPS }\end{array}$ & $\begin{array}{l}\text { Fold } \\
\text { change } \\
\text { over TH } \\
\text { (LPS) }\end{array}$ & $\begin{array}{l}\text { Change } \\
\text { in TH } \\
\text { with } \\
\text { LPS }\end{array}$ & $\begin{array}{l}\text { Change } \\
\text { in CD } \\
\text { with LPS }\end{array}$ & $\begin{array}{l}\text { Change } \\
\text { in AC } \\
\text { with } \\
\text { LPS }\end{array}$ & $\begin{array}{c}\text { Change } \\
\text { in CD/AC- } \\
\text { with LPS }\end{array}$ \\
\hline \multicolumn{9}{|c|}{ Toll-like Receptors and CD14 } \\
\hline TIr2 & $\mathrm{Cd} 11 \mathrm{~b}+$ & 41 & $\mathrm{Cd} 11 \mathrm{~b}+$ & 32 & & $\uparrow 4.0$ & & \\
\hline \multirow[t]{2}{*}{ TIr3 } & Acsa2+ & 8 & \multirow[t]{2}{*}{ Acsa2+ } & \multirow[t]{2}{*}{8} & & & \multirow[t]{2}{*}{$\uparrow 1.5$} & \\
\hline & $C d 11 b+$ & 5 & & & & & & \\
\hline TIr4 & $\mathrm{Cd} 11 \mathrm{~b}+$ & 25 & Cd11b+ & 18 & & $\downarrow 0.53$ & & \\
\hline Cd14 & $\mathrm{Cd} 11 \mathrm{~b}+$ & 75 & $C d 11 b+$ & 21 & & $\uparrow 2.6$ & & \\
\hline \multicolumn{9}{|c|}{ MyD88-Dependent Pathway } \\
\hline Myd88 & $\mathrm{Cd} 11 \mathrm{~b}+$ & 9 & $C d 11 b+$ & 6 & & $\uparrow 1.4$ & & \\
\hline Irak1 & $\mathrm{Cd} 11 \mathrm{~b}+$ & 2.5 & $\mathrm{Cd} 11 \mathrm{~b}+$ & 2.5 & & & & \\
\hline Irak4 & $\mathrm{Cd} 11 \mathrm{~b}+$ & 8 & Cd11b+ & 12 & & $\downarrow 0.64$ & & \\
\hline \multirow[t]{2}{*}{ Traf6 } & \multirow[t]{2}{*}{$\mathrm{Cd} 11 \mathrm{~b}+$} & \multirow[t]{2}{*}{2.5} & Acsa2+ & 2.5 & & & \multirow[t]{2}{*}{$\uparrow 2.1$} & \multirow[t]{2}{*}{$\uparrow 2.1$} \\
\hline & & & CD/AC- & 2 & & & & \\
\hline \multirow[t]{2}{*}{ Ikkb } & \multirow[t]{2}{*}{$\mathrm{Cd11b+}$} & \multirow[t]{2}{*}{3} & $C d 11 b+$ & 3 & & & & \\
\hline & & & Acsa2+ & 2 & & & & \\
\hline$\| 1 b$ & $C d 11 b+$ & $\begin{array}{l}\text { not detected } \\
\text { in TH }\end{array}$ & $\mathrm{Cd} 11 \mathrm{~b}+$ & 90 & & $\uparrow 1.6$ & & \\
\hline 116 & $C d 11 b+$ & $\begin{array}{l}\text { not detected } \\
\text { in TH }\end{array}$ & $C d 11 b+$ & 3.3 & & & & \\
\hline Tnf & none significant & & $C d 11 b+$ & 277 & & $\uparrow 13.7$ & & \\
\hline \multicolumn{9}{|c|}{ TRIF-Dependent Pathway } \\
\hline Trif & $\mathrm{Cd} 11 \mathrm{~b}+$ & 5 & $C d 11 b+$ & 4 & & $\downarrow 0.73$ & & \\
\hline Traf3 & none significant & & & & $\downarrow 0.62$ & & & \\
\hline Ikki & none significant & & $C d 11 b+$ & 6 & & $\uparrow 23.5$ & & \\
\hline \multirow[t]{3}{*}{ Irf3 } & $\mathrm{Cd} 11 \mathrm{~b}+$ & 4 & $C d 11 b+$ & 7 & & \multirow[t]{3}{*}{$\downarrow .79$} & & \\
\hline & Acsa2+ & 3 & Acsa2+ & 2.5 & & & & \\
\hline & CD/AC- & 2 & CD/AC- & 2.5 & & & & \\
\hline Ifnb & none significant & & $C d 11 b+$ & $\begin{array}{c}\text { not } \\
\text { detected } \\
\text { in TH }\end{array}$ & & $\begin{array}{c}\text { only } \\
\text { detected } \\
\text { with LPS }\end{array}$ & & \\
\hline Ccl5 & none significant & & $C d 11 b+$ & 13 & & $\uparrow 36.5$ & & \\
\hline Cxcl10 & none significant & & & & & & & \\
\hline
\end{tabular}




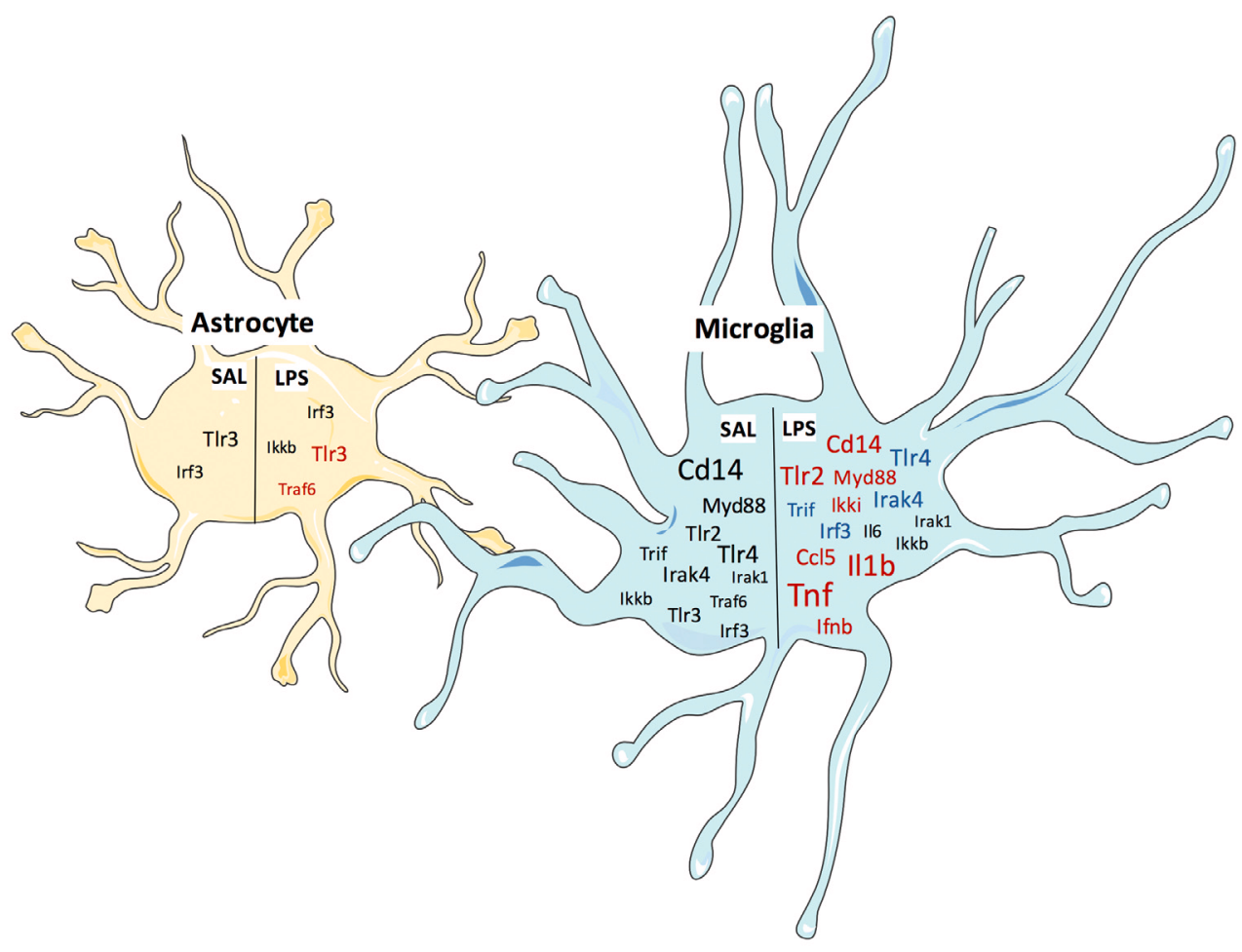

Figure 8. Summary of mRNA enrichment and LPS response. Microglial and astrocyte cell-type enrichment (compared to TH) is shown for TLR pathway genes in saline and LPS treated mice. The font size of each gene indicates fold-enrichment, with larger sizes meaning larger fold-enrichment. Colors on the LPS side denote whether that gene changed in that cell type with LPS treatment. Red indicates increased gene expression while blue denotes decreased gene expression. Figure created using http://servier.com/Powerpoint-image-bank.

It is surprising that the expression of Ifnb and $C c l 5$ is exclusively microglial. There is a trend towards increased expression of $\mathrm{Cxcl10}$ in both astrocytes and microglia after LPS, suggesting that the TRIF-dependent pathway is being activated and inducing downstream signaling in both cell types. This raises the question of how expression of $\mathrm{Cxcl10}$ is increased without Ifnb there to induce it. It is possible that interferon-inducible genes are produced in response to IFN $\beta$ in microglia, but changed in a different manner in astrocytes, which lack a macrophage lineage. Astrocytes produce interferon in a TLR3 and TLR4 dependent manner in vitro ${ }^{43,44}$, but it is possible that astrocytes respond differently in vivo. It is also plausible that the inflammatory response is temporally mediated within each cell-type, and that increased expression of interferons would be detected in astrocytes if evaluated earlier or later. It is noteworthy that TLR4 also signals through the TRIF-dependent pathway and is highly microglial, so perhaps TLR3 signaling is predominant in astrocytes, while TLR4-induced TRIF dependent signaling dominates in microglia, leading to the increased Ifnb, Ccl5, and Cxcl10 seen in the CD11b+ fraction.

Components of the MyD88 pathway were highest expressed in microglia, which is consistent with expression of Tlr2 and Tlr4. However, some components of this pathway (Irakl, Traf6, Ikkb) were more evenly distributed across the fractions, and Traf6 expression increased in the astrocyte fraction following LPS. The different expression profiles could be because Traf6 can also be activated via TRIF in response to TLR3 or TLR4, and is involved in other pathways like TGF- $\beta$ signaling. Additionally, Ikkb is involved in every pathway that signals to NF- $\kappa \mathrm{B}$, not just TLR pathways. Consistent with the notion that MyD88-dependent signaling is mostly occurring in microglia, $I l 1 b$, Il6, and Tnf expression were primarily microglial. However, there is a trend towards an increase in $I l 6$ seen in astrocytes and the $\mathrm{CD} / \mathrm{AC}$ - negative fraction in response to LPS. There is evidence that $I l 6$ is also activated in response to LPS and TRIF-dependent signaling in cultured astrocytes ${ }^{18,42}$, so it is possible that TRIF-dependent increases in $I l 6$ expression occur in astrocytes in vivo.

It is worth noting that although several robust changes were observed in response to LPS within the cell fractions, none were observed in the total homogenate, which is the typical preparation for evaluation of gene expression. This highlights the importance of looking at discrete cell types when evaluating immune changes in the brain, particularly because expression could be decreasing in one cell type while increasing in another (as seen with Tlr3). A caveat to collecting cell fractions is that whole brain samples had to be pooled to get enough RNA for RT-qPCR. Because of this, any brain-region specific changes are missed and the statistical power is reduced. Furthermore, the primers used for RT-qPCR are designed to target a single exon-exon junction, so exon level expression and splice variants may be missed. 
Although expression of mRNA and protein is not always $1: 1$, we were unable to find any examples in the literature showing all mRNA changes occurring in one cell-type and all protein changes occurring in a different cell-type. Because this is what our preliminary data suggested, we sought to test our hypothesis that many copies of mRNA were found inside microglia to ensure rapid translation in response to danger signals (although this hypothesis did not address why protein was found in neurons). After this study, we are just as unclear, if not more, about the protein localization of TLR signaling molecules. However, we do have some thoughts as to what is causing this confusion.

The western blots we performed show incredibly variable expression profiles, but the most concerning result is that several TLR signaling proteins do not appear to be expressed in microglia (TLR2, TLR3, MyD88 sc-11356, Irak1, IKK $\beta$ ), even though all of them show microglial mRNA expression and most show highest expression in microglia. However, after some quality control steps, we are unable to trust any of the protein results. For the antibodies we could test, all but one showed expression in a negative control. For the antibodies we were unable to test on null mutant tissue, we erred on the side of caution and assumed they were also non-specific. Furthermore, different antibodies to the same protein gave very different expression profiles (Figure 7C), reaffirming that the antibodies cannot be trusted. We suspect that antibody specificity is one of the major reasons for disagreement in the field. Even though other researchers have told us that TLR antibodies are notoriously non-specific, they continue to be used in publications and these results continue to be cited as accurate. Even resources like the human protein atlas use antibodies to determine cell type localization ${ }^{26}$. For example, the data for MyD88 in the human protein atlas suggests that protein is highly neuronal, but RNA expression is mostly glial. Interestingly, the antibody they use is sc-11356, which we found to be non-specific (Figure 6F). They do provide information about the antibody validation, but they are basing the validation on comparison of staining in one tissue type (colon) to the literature.

It isn't surprising that antibodies are non-specific, given that most manufacturers only validate them in transfected cell lines or with blocking peptide. Some companies, when asked, could not even suggest a negative control and claimed it would be too difficult to test all antibodies on knockout tissue. Unless this practice changes, every lab needs to test the antibody in their hands with positive and negative controls to be confident their results are accurate. Due to the difficulty of testing several antibodies for each protein, other approaches may be better suited for looking at several proteins at once. Proteomic approaches in glial cells have revealed protein changes that more closely match what is expected ${ }^{45}$. Alternatively, construction of transgenic mice with GFP-tagged expression of TLR genes may be useful to show the CNS cell-type localization.

In addition to our western blots, our immunohistochemistry and in situ results suggest that glial cells are less likely to be permeable to probes or antibodies. Therefore, more stringent permeabilization steps may be needed to detect intracellular molecules in glia. Although we attempted different permeabilization steps, we continued to see neuronal localization.
In conclusion, this study confirms and expands on mRNA cell-type localization of TLR signaling molecules and evaluates cell-type specific increases following LPS administration. This study was unable to reliably determine the protein localization of TLR signaling molecules, and we suggest this is due to non-specific antibodies and problems with permeabilization. We suggest that future studies evaluating cell-type expression take these results into account and that perhaps other non-antibody approaches be used to determine the protein localization of this important pathway in the CNS.

\section{Data availability \\ Dataset 1. Dataset containing six files as follows:}

IHC localization images: This folder contains all immunohistochemistry images for MyD88, Irak1, and Traf6. The MyD88 folder contains images from 4 different MyD88 antibodies.

- Images summary: Powerpoint file containing images for neuronal staining overlayed with each antibody

- Irak1

$\circ$ Irak1 and NeuN

- TIF images for Irak1, NeuN, and merged

$\circ \mathrm{MyD} 88$

- Table summarizing staining in human brain overlayed with NeuN (JPG file)

- Powerpoint file summarizing MyD88 staining in primary neuronal cultures

- MyD88 Abcam 2064 antibody: TIF files for MyD88, Neun, and merge

- MyD88 F-19 antibody

- MyD88 and GFAP: TIF or JPG files showing staining for MyD88, GFAP (astrocyte marker), and merge

- Myd88 and Iba1: TIF, PSD, and JPG files showing staining for MyD88, Iba1 (microglial marker) and merge

- MyD88 and NeuN: TIF and JPG files showing staining for MyD88, NeuN (neuronal marker), and merge

- MyD88 S.Cruz Full length (HFL-296): TIF files for MyD88, NeuN and merge

ISH images: This folder contains in situ images and information

- Confocal images: Contains confocal images as TIF files showing IRF3, IBA1 and merge

- Summary of fluorescent microscope images: Contains TIF images and word documents with representative images for in situs (probe, protein, and merged)

- ISH testing summary: excel file containing all information about different in situ tests 
Knockout animal qPCR: This folder contains Biorad CFX data files and genes study as well as GraphPad file of data and statistical analysis

Sal-LPS qPCR data: This folder contains all Biorad CFX data files as well as an excel file showing data from the gene study (CFX analysis for multiple plates). It also contains a GraphPad file of all data and statistical tests.

Sal-LPS western blots: This folder contains all raw western blot images used in Figure 7 (as TIF files).

Validation western blots: This folder contains all raw western blot images used in Figure 6 (as TIF files). doi, 10.5256/f1000research.12036.d168396 $6^{46}$

\section{Competing interests}

No competing interests were disclosed.

Grant information

Funding for this work was provided by the National Institute on Alcohol Abuse and Alcoholism (grants AA024654 and AA013520).

\section{Acknowledgements}

The authors thank Olga Ponomareva, Jillian Benavidez, Mendy Black, and Adriana DaCosta for their technical assistance.

\section{Supplementary material}

Figure S1: Schematic of study methods. The mice were divided into three subgroups, each containing 5 mice per treatment. Mice were injected with either saline or $2 \mathrm{mg} / \mathrm{kg}$ LPS and sacrificed 24-hours later. The whole brain was removed and tissue was pooled within each group by treatment yielding 3 biological replicates per treatment. $1 \%$ of minced tissue was taken as total homogenate and the remaining tissue was used to isolate microglia $(\mathrm{Cd} 11 \mathrm{~b}+)$ and astrocytes (Acsa2+). The remaining cells (Cd11b/Acsa2) were also collected. 10\% of each sample was used for RNA isolation and RT-qPCR and $90 \%$ was used for protein isolation and western blots.

Click here to access the data.

Figure S2: Weights and water consumption after LPS. Data verifying the effect of LPS treatment. A. All 3 LPS groups showed decreased weight following injection, data points are averages of 5 mice. B. All 3 LPS groups decreased water consumption following LPS injection, data points are averages of 5 mice.

Click here to access the data.

Figure S3: Knockout mouse qPCR. RT-qPCR on knockout mouse brain compared to wild type (C57/B16J). A. TLR4 knockout tissue showed no Tlr4 mRNA expression. B. TLR2 knockout tissue showed an increase in Tlr2 expression. C. MyD88 knockout tissue showed a decrease in Myd88 expression. * $\mathrm{p}$ value $<0.05,2$-tailed t-test, $\mathrm{n}=10$ per group.

Click here to access the data.

Figure S4: Immunohistochemistry for MyD88, IRAK1, and TRAF6. Representative images from immunohistochemistry evaluation of MyD88 ( $n=10)$, IRAK1 $(n=4)$, and TRAF6 $(n=5)$ expression in the mouse cortex revealed co-localization with the neuronal maker NEUN. Additional images are available in the source data files.

Click here to access the data.

Figure S5: In situ hybridization for Irf3 and microglial marker Tmem119. In situ hybridization compared mRNA expression with cell-type markers. A. Irf3 mRNA shows little overlap with the microglial marker IBA1 (3 biological replicates with at least 3 technical replicates each). B. Irf3 mRNA shows high overlap with the neuronal marker NEUN (2 biological replicates with 2 technical replicates each). C. Tmem119, a microglial marker, shows little overlap with IBA1 (2 biological replicates with 2 technical replicates each). D. Tmem119 shows overlap with the neuronal marker NEUN (1 biological replicate).

Click here to access the data.

Table S1: Taqman gene expression assays used for RT-qPCR.

Click here to access the data.

Table S2: Antibodies used for western blots.

Click here to access the data.

Table S3: Immunohistochemistry and in situ antibodies/probes. A. Antibodies used for immunohistochemistry, results in Figure S4. B. Probes used for in situ hybridization, results in Figure S5. C. Antibodies used for in situ hybridization, results in Figure S5.

Click here to access the data.

Table S4: Results of statistical tests. This table contains all input data and statistical results for the qPCR data presented in the manuscript. Data in this table is extracted from the GraphPad file included in the source data.

Click here to access the data. 
1. Kawai T, Akira S: Signaling to NF-kappaB by Toll-like receptors. Trends Mol Med. 2007; 13(11): 460-469.

PubMed Abstract | Publisher Full Text

2. Takeda K, Akira S: TLR signaling pathways. Semin Immunol. 2004; 16(1): 3-9. PubMed Abstract | Publisher Full Text

3. Takeda K, Akira S: Toll-like receptors in innate immunity. Int Immunol. 2005; 17(1): 1-14.

PubMed Abstract | Publisher Full Text

4. García Bueno B, Caso JR, Madrigal JL, et al.: Innate immune receptor Toll-like receptor 4 signalling in neuropsychiatric diseases. Neurosci Biobehav Rev. 2016; 64: 134-147.

PubMed Abstract | Publisher Full Text

5. Gasiorowski K, Brokos B, Echeverria V, et al:: RAGE-TLR Crosstalk Sustains Chronic Inflammation in Neurodegeneration. Mol Neurobiol. 2017; 12: 593. PubMed Abstract | Publisher Full Text

6. Gambuzza ME, Sofo V, Salmeri FM, et al.: Toll-like receptors in Alzheimer's disease: a therapeutic perspective. CNS Neurol Disord Drug Targets. 2014; 13(9): 1542-1558.

PubMed Abstract | Publisher Full Text

7. Gesuete R, Kohama SG, Stenzel-Poore MP: Toll-like receptors and ischemic brain injury. J Neuropathol Exp Neurol. 2014; 73(5): 378-386.

PubMed Abstract | Publisher Full Text | Free Full Text

8. Crews FT, Walter TJ, Coleman LG Jr, et al:: Toll-like receptor signaling and stages of addiction. Psychopharmacology (Berl). 2017; 234(9-10): 1483-1498. PubMed Abstract | Publisher Full Text | Free Full Text

9. Hanke ML, Kielian T: Toll-like receptors in health and disease in the brain: mechanisms and therapeutic potential. Clin Sci (Lond). 2011; 121(9): 367-387. PubMed Abstract | Publisher Full Text | Free Full Text

10. Bsibsi M, Ravid R, Gveric D, et al.: Broad expression of Toll-like receptors in the human central nervous system. J Neuropathol Exp Neurol. 2002; 61(11): 1013-1021.

PubMed Abstract | Publisher Full Text

11. Lehnardt S, Lachance C, Patrizi S, et al:: The toll-like receptor TLR4 is necessary for lipopolysaccharide-induced oligodendrocyte injury in the CNS. J Neurosci. 2002; 22(7): 2478-2486.

PubMed Abstract

12. Olson JK, Miller SD: Microglia initiate central nervous system innate and adaptive immune responses through multiple TLRs. J Immunol. 2004; 173(6): 3916-3924.

PubMed Abstract | Publisher Full Text

13. Kielian $\mathrm{T}$ : Toll-like receptors in central nervous system glial inflammation and homeostasis. J Neurosci Res. 2006; 83(5): 711-730. PubMed Abstract | Publisher Full Text | Free Full Text

14. Gorina R, Font-Nieves M, Márquez-Kisinousky L, et al.: Astrocyte TLR4 activation induces a proinflammatory environment through the interplay between MyD88dependent NFKB signaling, MAPK, and Jak1/Stat1 pathways. Glia. 2011; 59(2): 242-255.

PubMed Abstract | Publisher Full Text

15. Borysiewicz E, Doppalapudi S, Kirschman LT, et al:: TLR3 ligation protects human astrocytes against oxidative stress. J Neuroimmunol. 2013; 255(1-2): $54-59$.

PubMed Abstract | Publisher Full Text

16. Park C, Lee $\mathrm{S}$, Cho IH, et al:: TLR3-mediated signal induces proinflammatory cytokine and chemokine gene expression in astrocytes: Differential signaling mechanisms of TLR3-induced IP-10 and IL-8 gene expression. Glia. 2006; 53(3): 248-256.

PubMed Abstract | Publisher Full Text

17. Blanco AM, Vallés SL, Pascual M, et al:: Involvement of TLR4/type I IL-1 receptor signaling in the induction of inflammatory mediators and cell death induced by ethanol in cultured astrocytes. J Immunol. 2005; 175(10): 6893-6899. PubMed Abstract | Publisher Full Text

18. Marinelli C, Di Liddo R, Facci L, et al.: Ligand engagement of Toll-like receptors regulates their expression in cortical microglia and astrocytes.

J Neuroinflammation. 2015; 12: 244.

PubMed Abstract | Publisher Full Text | Free Full Text

19. Liu XJ, Liu T, Chen G, et al.: TLR signaling adaptor protein MyD88 in primary sensory neurons contributes to persistent inflammatory and neuropathic pain and neuroinflammation. Sci Rep. 2016; 6: 28188. PubMed Abstract | Publisher Full Text | Free Full Text

20. Aurelian L, Warnock KT, Balan I, et al.: TLR4 signaling in VTA dopaminergic neurons regulates impulsivity through tyrosine hydroxylase modulation. Transl Psychiatry. 2016; 6: e815.

PubMed Abstract | Publisher Full Text | Free Full Text

21. Peltier DC, Simms A, Farmer JR, et al:: Human neuronal cells possess functional cytoplasmic and TLR-mediated innate immune pathways influenced by phosphatidylinositol-3 kinase signaling. J Immunol. 2010; 184(12): 7010-7021. PubMed Abstract | Publisher Full Text | Free Full Text
22. Préhaud $\mathrm{C}$, Mégret $\mathrm{F}$, Lafage $\mathrm{M}$, et al:: Virus infection switches TLR-3-positive human neurons to become strong producers of beta interferon. $J$ Virol. 2005; 79(20): 12893-12904.

PubMed Abstract | Publisher Full Text | Free Full Text

23. Qi J, Buzas $\mathrm{K}$, Fan $\mathrm{H}$, et al.: Painful pathways induced by TLR stimulation of dorsal root ganglion neurons. J Immunol. 2011; 186(11): 6417-6426. PubMed Abstract | Publisher Full Text | Free Full Text

24. Crews FT, Qin L, Sheedy D, et al.: High mobility group box $1 /$ toll-like receptor danger signaling increases brain neuroimmune activation in alcoho dependence. Biol Psychiatry. 2013; 73(7): 602-612. PubMed Abstract | Publisher Full Text | Free Full Text

25. Zhang $\mathrm{Y}$, Chen $\mathrm{K}$, Solan SA, et al:: An RNA-sequencing transcriptome and splicing database of glia, neurons, and vascular cells of the cerebral cortex. $J$ Neurosci. 2014; 34(36): 11929-11947.

PubMed Abstract | Publisher Full Text | Free Full Text

26. Uhlén M, Fagerberg L, Hallström BM, et al:: Proteomics. Tissue-based map of the human proteome. Science. 2015; 347(6220): 1260419.

PubMed Abstract | Publisher Full Text

27. Lawrimore CJ, Crews FT: Ethanol, TLR3, and TLR4 agonists have unique innate immune responses in neuron-like SH-SY5Y and microglia-like BV2. Alcohol Clin Exp Res. 2017; 41(5): 939-954.

PubMed Abstract | Publisher Full Text | Free Full Text

28. Rosenberger K, Derkow K, Dembny $\mathrm{P}$, et al.: The impact of single and pairwise Toll-like receptor activation on neuroinflammation and neurodegeneration. $J$ Neuroinflammation. 2014; 11: 166.

PubMed Abstract | Publisher Full Text | Free Full Text

29. June HL, Lie J, Warnock KT, et al.: CRF-amplified neuronal TLR4/MCP-1 signaling regulates alcohol self-administration. Neuropsychopharmacology. 2015; 40(6): 1549-1559.

PubMed Abstract | Publisher Full Text | Free Full Text

30. Butovsky O, Jedrychowski MP, Moore CS, et al:: Identification of a unique TGF- $\beta$-dependent molecular and functional signature in microglia. Nat NeurosCi. 2014; 17(1): 131-143.

PubMed Abstract | Publisher Full Text | Free Full Text

31. Béchade $\mathrm{C}$, Colasse $\mathrm{S}$, Diana MA, et al: NOS2 expression is restricted to neurons in the healthy brain but is triggered in microglia upon inflammation. Glia. 2014; 62(6): 956-963.

PubMed Abstract | Publisher Full Text

32. Blednov YA, Black M, Chernis J, et al.: Ethanol Consumption in Mice Lacking CD14, TLR2, TLR4, or MyD88. Alcohol Clin Exp Res. 2017; 41(3): 516-530. PubMed Abstract | Publisher Full Text | Free Full Text

33. Werts C, Tapping RI, Mathison JC, et al:: Leptospiral lipopolysaccharide activates cells through a TLR2-dependent mechanism. Nat Immunol. 2001; 2(4): 346-352.

PubMed Abstract | Publisher Full Text

34. Poltorak A, He X, Smirnova I, et al.: Defective LPS signaling in $\mathrm{C} 3 \mathrm{H} / \mathrm{HeJ}$ and C57BL/10ScCr mice: mutations in TIr4 gene. Science. 1998; 282(5396): 2085-2088. PubMed Abstract | Publisher Full Text

35. Hou B, Reizis B, DeFranco AL: Toll-like receptors activate innate and adaptive immunity by using dendritic cell-intrinsic and -extrinsic mechanisms. Immunity 2008; 29(2): 272-282.

PubMed Abstract | Publisher Full Text | Free Full Text

36. Wooten RM, Ma Y, Yoder RA, et al:: Toll-like receptor 2 is required for innate, but not acquired, host defense to Borrelia burgdorferi. J Immunol. 2002; 168(1): 348-355.

PubMed Abstract | Publisher Full Text

37. Nikodemova M, Watters JJ: Efficient isolation of live microglia with preserved phenotypes from adult mouse brain. J Neuroinflammtion. 2012; 9: 147. PubMed Abstract | Publisher Full Text | Free Full Text

38. Bustin SA, Benes V, Garson JA, et al:: The MIQE quidelines: minimum information for publication of quantitative real-time PCR experiments. Clin Chem. 2009; 55(4): 611-622.

PubMed Abstract | Publisher Full Tex

39. Truitt JM, Blednov YA, Benavidez JM, et al: Inhibition of IKK $\beta$ Reduces Ethanol Consumption in C57BL/6J Mice. eNeuro. 2016; 3(5): pii: ENEURO.0256-16.2016. PubMed Abstract | Publisher Full Text | Free Full Text

40. Bennett ML, Bennett FC, Liddelow SA, et al:: New tools for studying microglia in the mouse and human CNS. Proc Natl Acad Sci U S A. 2016; 113(12): E1738-46. PubMed Abstract | Publisher Full Text | Free Full Text

41. Scumpia PO, Kelly KM, Reeves WH, et al:: Double-stranded RNA signals antiviral and inflammatory programs and dysfunctional glutamate transport in TLR3-expressing astrocytes. Glia. 2005; 52(2): 153-162.

PubMed Abstract | Publisher Full Text

42. Jack CS, Arbour N, Manusow J, et al.: TLR signaling tailors innate immune responses in human microglia and astrocytes. J Immunol. 2005; 175(7): 4320-4330.

PubMed Abstract | Publisher Full Text 
43. Reinert LS, Harder L, Holm CK, et al:: TLR3 deficiency renders astrocytes permissive to herpes simplex virus infection and facilitates establishment of CNS infection in mice. J Clin Invest. 2012; 122(4): 1368-1376. PubMed Abstract | Publisher Full Text | Free Full Text

44. Pascual-Lucas M, Fernandez-Lizarbe S, Montesinos J, et al.: LPS or ethanol triggers clathrin- and rafts/caveolae-dependent endocytosis of TLR4 in cortical astrocytes. J Neurochem. 2014; 129(3): 448-462.

PubMed Abstract | Publisher Full Text
Bell-Temin H, Zhang P, Chaput D, et al:: Quantitative proteomic characterization of ethanol-responsive pathways in rat microglial cells. J Proteome Res. 2013; 12(5): 2067-2077.

PubMed Abstract | Publisher Full Text

46. McCarthy GM, Bridges CR, Blednov YA, et al:: Dataset 1 in: CNS cell-type localization and LPS response of TLR signaling pathways. F1000Research. 2017.

Data Source 


\title{
Open Peer Review
}

\section{Current Peer Review Status:}

\author{
Version 1
}

Reviewer Report 27 September 2017

https://doi.org/10.5256/f1000research.13022.r26347

(c) 2017 Herkenham M. This is an open access peer review report distributed under the terms of the Creative Commons Attribution License, which permits unrestricted use, distribution, and reproduction in any medium, provided the original work is properly cited.

\section{Miles Herkenham}

National Institute of Mental Health, National Institutes of Health, Bethesda, MD, USA

I recommend adding text to the Discussion to include supporting data for the conclusion that TLR4, TLR2, and their related signaling components shown in Figure 1 are localized primarily to microglia, secondarily to vascular endothelia, and least in neurons. There are several sources of supporting data that should be described and cited. First, and the most expansive, is the RNA-Seq database available at the Barres Lab Stanford RNA-Seq Transcriptome website at https://web.stanford.edu/group/barres_lab/brain_rnaseq.html. The database is derived from the work published by Zhang et al., 2014 (ref 25). The interactive site provides gene expression levels of most genes of interest, including the TLRs and all the signaling components shown in Figure 1. In agreement with the data in the McCarthy study, TIr4 mRNA expression levels, provided in values of fragments per kilobase of exon per million reads mapped (FPKM), are highest in microglia (3), second in endothelia (2.3), and very low in all other cell types ( 0.3-0.4 on astrocytes and OPCs, and $\sim 0.1$ on neurons). TIr2 mRNA is abundantly and almost exclusively expressed in microglia $(>150)$. All of the downstream co-factors and pathways are predominantly expressed in microglia, with the exception of the side-chain pathway via TRAF3 and IRF3, which is expressed in all the cell types. The cytokine mRNAs measured by McCarthy, and others such as IL-1b and TNFa, are almost exclusively expressed in microglia. Finally, for TLR3, the FPKM values are astrocytes (13), endothelia (9), microglia (2.5), and neurons $(<1.0)$.

Next, the authors should note that earlier in situ hybridization studies showed TIr4 mRNA expressed in a variety of blood-brain barrier cell types including choroid plexus epithelial cells, meningeal cells, vascular endothelial cells (Laflamme and Rivest, 2001, DOI:10.1096/fj.00-0339com ; Chakravarty and Herkenham, 2005, DOI: 10.1523/JNEUROSCI.4268-04.2005), and within the brain, microglial cells (Chakravarty, 2005). Supporting the microglial localization, a recent article used the very sensitive and specific RNAscope (ACD) colorimetric methodology to co-localize TIr4 mRNA and Iba1 mRNA (Kashima, 2017, DOI:10.1073/pnas.1705974114) and showed that in the nucleus accumbens, the microglia-TLR4 double-labeled population was the majority ( $80 \%)$ of all TIr4 mRNA-positive cells. Finally, the early in situ hybridization autoradiographic work also showed that the TLR4 mRNA expression level was downregulated by LPS at $3 \mathrm{~h}$ post-injection (Laflamme and Rivest, 2001), in support of McCarthy's findings with qPCR. 
A TLR4-bearing cell population overlooked by McCarthy et al. in terms of LPS responsiveness is endothelial cells, which strongly express T/r4 mRNA. These cells are the major first responders to LPS (Serrats, 2010, DOI: 10.1016/j. neuron.2009.11.032). It is not clear whether this population survived the separation procedure used by McCarthy.

The LPS stimulation data in the report are supported by other published data, but the experiment was not performed optimally because the 24-h survival time selected was too long. There is an early response to LPS (0.5-2 h) that is chiefly mediated by cells at the blood-brain barrier, and later responses, indicated by induction of IkB and cytokine mRNAs within microglia (Quan, 1997, PMID: 9380746; Quan, 1998 , PMID: 10378870) might be prostaglandin- or cytokine-mediated (Serrats, 2010). Note that LPS does not significantly cross the blood brain barrier. At $12 \mathrm{~h}$ post-LPS, most responses have died down, and at $24 \mathrm{~h}$, the initial LPS-mediated effects have dropped to near zero (Quan, 1998; Serrats, 2010).

Nevertheless, the inclusion of LPS data raises another important observation that should be addressed-neurons are unresponsive to LPS. We reported that primary cultured mouse cortical and hippocampal neurons do not show activation of NF-kB pathways by LPS, indicating that they do not possess functional TLR4 (Listwak, 2013, DOI: 10.1016/j.neuroscience.2013.07.013). Microglia, in contrast, have a massive response to LPS.

McCarthy et al. importantly address the lack of specificity of antibodies. That conclusion is also supported by our work on the NF-kB pathways. We attacked that problem in our study showing that many of the published antibodies for the NF-kB subunits p65 and p50 and their activated (phosphorylated) forms were nonspecific (Herkenham, 2011, DOI: 10.1186/1742-2094-8-141). The use of these antibodies had supported the claim in the literature that NF-kB is active in neurons. Thus, we heartily agree that antibodies are not specific in many studies of TLR pathways, especially for immunohistochemistry and especially when epitope levels are low. We endorse the increased demand for rigor in use of antibodies imposed by many journals and by the NIH grant review process. It would be helpful if McCarthy could mention these new demands for rigor, which will raise awareness of the burdens caused by improper antibody use.

My main objection to McCarthy study is the poor quality of their in situ hybridization based on use of locked nucleic acid (LNA) probes and digoxygenin detection. I would recommend that future work be done with the new highly sensitive and selective probes from ViewRNA (Affymetrix) or RNAscope (ACD).

Is the work clearly and accurately presented and does it cite the current literature? Partly

Is the study design appropriate and is the work technically sound? Partly

Are sufficient details of methods and analysis provided to allow replication by others? Yes

If applicable, is the statistical analysis and its interpretation appropriate? 


\section{Not applicable}

Are all the source data underlying the results available to ensure full reproducibility? Yes

\section{Are the conclusions drawn adequately supported by the results?} Yes

Competing Interests: No competing interests were disclosed.

\section{I confirm that I have read this submission and believe that I have an appropriate level of expertise to confirm that it is of an acceptable scientific standard.}

Reviewer Report 16 August 2017

\section{https://doi.org/10.5256/f1000research.13022.r24588}

(C) 2017 Okun E. This is an open access peer review report distributed under the terms of the Creative Commons Attribution License, which permits unrestricted use, distribution, and reproduction in any medium, provided the original work is properly cited.

\section{Eitan Okun}

The Mina and Everard Goodman Faculty of Life Sciences, Bar-Ilan University, Ramat Gan, Israel

In this paper, Gizelle, Courtney, Yuri and Adron have undertook a difficult task of determining the expression pattern of Toll-like receptors (TLRs), their adapter proteins and downstream effector proteins in CNS cells. This is an important and timely work which emphasizes the importance of establishing the appropriate tools in order to advance an entire field.

After reading the manuscript, I'd like to raise the following points:

1. Technical comment: under "tissue harvest and microglial isolation", it is described that the used kit for tissue dissociation uses papain. Is it possible that this type of dissociation degraded some of the extracellular epitopes and altered their expression in subsequent western blots? Perhaps it should be cautioned that different enzymes or dissociation methods can result in different outcomes.

2. Under "protein isolation and western blots", it is mentioned that appropriate loading controls could not be found for all cell types. This is understandable, as specialized CNS cells contain different levels of proteins such as beta-actin, alpha tubulin, beta tubulin and others. Please indicate which proteins were tested in your hands.

3. With respect to the probes used for in-situ hybridization, it is entirely possible that different cells will express different splice variants of the genes. Has that been taken into consideration?

4. On page 6, results section, it is unclear to me why there is a lack of NeuN expression in the CD11-/ACSA2- fraction (Figure 2C). Should it not contain neuronal cells? 
5. On the 2 nd results paragraph, the fold change in expression of the different genes is indicated. I think that it should be further stressed that despite the fact that fold changes are important to note, the very expression, even though it is in smaller levels, of TLRs 2,3 and 4 is present in non-microglial cells.

6. On page 7, under "antibody validation in knockout tissue and HEK-293 cells". It is debatable whether post-translational modification can alter the size of a protein in a gel. Also, a KO tissue which lacks the target of the antibody can still express a target which will be secondin-highest affinity in absence of the original target. therefore, overexpressing the target of interest (TLR2,3,4 etc fused to GFP) will determine clearly whether the commercial antibody is capable of binding its target. This way, if the antibody cannot bind its target TLR but GFP can be detected, this is a definite proof that the antibody fails to detect its target under these conditions.

7. Table $\mathrm{S} 2$ should also include specification of the declared application for the antibody by the manufacturer, whether it is denaturative WB, IHC, ELISA etc...

8. On the same note, although this information is often missing from datasheets of commercial antibodies, the epitope used to vaccinate against should be indicated.

9. On page 13, the issue of a microglial-specific marker, Tmem119, not being detected on microglail cells using the described protocol is of concern. I understand that $0.1 \%$ Tween-20 was used. Is it possible that a more harsh detergent at a higher concentration would solve this issue? For example - $0.5-1 \%$ triton- $x$ ?

10. In the discussion, the issue of expression of adapter-protein expression in various cells is discussed. Despite the fact that MyD88 is a signaling mediator of the IL1R family, which is also reported to be abundantly expressed in the brain, it is not discussed in the paper. Therefore, the expression of certain signaling molecules could be the result of pathways unrelated to TLRs but rather to other immune receptors such as IL1R.

11. On the last sentence on page 15, the authors rightfully, and correctly indicated that the current analysis cannot take into consideration any brain-region specific expressions, and that the probes used cannot address alterations in splice variants. This by itself could draw the conclusion that a similar effort should concentrate at a specific TLR at a time, studying the different splice variants in details throughout the brain.

Minor points:

1. Page 4, left column, the end of the second paragraph - a reference has to be added following "expression in neurons".

2. Same page, right column, lines $3-4$, immune activation is exemplified by LPS. I think that it should be stated that it is TLR4-specific immune activation, as there are numerous ways to activate the immune response by different pathways.

3. Please abbreviate "MS" in page 5, left column: "eluted using MS columns". 
4. Same page, right column, please abbreviate "NBF": "in 10\% NBF overnight.."

5. On page 16, first sentence, $i$ think that it is better to replace 1:1 with 'correlative', as 1:1 relates to quantifiable ratios, whereas the agreement between mRNA to proteins is describes as trends.

Is the work clearly and accurately presented and does it cite the current literature? Yes

Is the study design appropriate and is the work technically sound? Partly

Are sufficient details of methods and analysis provided to allow replication by others? Yes

If applicable, is the statistical analysis and its interpretation appropriate?

Yes

Are all the source data underlying the results available to ensure full reproducibility? Yes

Are the conclusions drawn adequately supported by the results?

Yes

Competing Interests: No competing interests were disclosed.

Reviewer Expertise: Neuroimmunology

I confirm that I have read this submission and believe that I have an appropriate level of expertise to confirm that it is of an acceptable scientific standard. 
The benefits of publishing with F1000Research:

- Your article is published within days, with no editorial bias

- You can publish traditional articles, null/negative results, case reports, data notes and more

- The peer review process is transparent and collaborative

- Your article is indexed in PubMed after passing peer review

- Dedicated customer support at every stage

For pre-submission enquiries, contact research@f1000.com 